\title{
Asymmetrical magnetic fabrics in the Egersund doleritic dike swarm (SW Norway) reveal sinistral oblique rifting before the opening of the Iapetus
}

\author{
Salvatrice Montalbano ${ }^{\text {a, }}{ }^{*}$, Hervé Diot ${ }^{\mathrm{b}, \mathrm{c}}$, Olivier Bolle ${ }^{\mathrm{a}}$ \\ ${ }^{a}$ Département de Géologie, Université de Liège, Quartier Agora, Allée du Six Août 12, 4000 Liège, Belgium \\ ${ }^{\mathrm{b}}$ UMR-CNRS 6112, Laboratoire de Planétologie et Géodynamique, Université de Nantes, 2 Rue de la Houssinière, 44322 Nantes Cedex 3, France

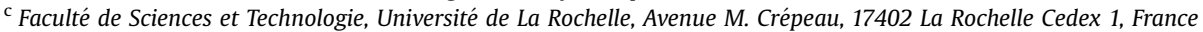

\section{A R T I C L E I N F O}

\section{Article history:}

Received 15 September 2015

Received in revised form

15 January 2016

Accepted 25 January 2016

Available online 1 February 2016

Keywords:

Ediacaran

Dolerite

Rogaland

Anisotropy of magnetic susceptibility

Transtension

Tornquist zone

\begin{abstract}
A B S T R A C T
The $616 \pm 3 \mathrm{Ma}$ (Ediacaran) Egersund doleritic dike swarm cuts across the Rogaland anorthosite province and its granulitic country rocks, in SW Norway. The structure of eight out of eleven main dikes of the swarm was investigated using the anisotropy of magnetic susceptibility (AMS) technique. Thermomagnetic data and values of the bulk magnetic susceptibility reveal a magnetic mineralogy dominated by Tipoor titanomagnetite. Magnetic fabric and global petrofabric are coaxial, except in sites strongly affected by hydrothermal alteration, as demonstrated through image analysis. Asymmetrical dispositions of the magnetic foliation and lineation support the existence of a syn-emplacement, sinistral strike-slip shearing resolved on dike walls. Such asymmetrical fabrics are attributed to a transtension tectonic regime, in a context of oblique extension during the continental rifting phase which preceded the opening of the Iapetus Ocean along the SW margin (present-day orientation) of Baltica.
\end{abstract}

(ङ) 2016 Elsevier Ltd. All rights reserved.

\section{Introduction}

The anisotropy of magnetic susceptibility (AMS) in a rock records the preferred orientation-distribution of all minerals (i.e. dia-, para- and ferromagnetic), hence AMS is able to reveal subtle fabrics in apparently isotropic rocks (Rochette et al., 1992; Bouchez, 2000; Borradaile and Jackson, 2004). This powerful tool has been extensively used over the last three decades to quantify the fabric of volcanic dikes, revealing magma flow direction and, possibly, flow sense and relative location of the feeding magma chamber(s) (Knight and Walker, 1988; Rochette et al., 1991; Ernst and Baragar, 1992; Raposo and Ernesto, 1995; Varga et al., 1998; Geoffroy et al., 2002; Borradaile and Gauthier, 2006; Aubourg et al., 2008; Silva et al., 2010; among others). AMS in volcanic dikes may also help in deciphering any syn-emplacement tectonic shearing parallel to the dike walls (Féménias et al., 2004; Creixell et al., 2006; Clemente et al., 2007).

This paper presents an AMS study of the Ediacaran (late-

\footnotetext{
* Corresponding author.

E-mail address: s.montalbano@ulg.ac.be (S. Montalbano).
}

Neoproterozoic) Egersund doleritic dike swarm of SW Norway, considered as a precursor of the opening of the lapetus Ocean in the area (e.g. Torsvik et al., 1996). The AMS sampling was conducted along transversal sections in order to evidence any variation of the orientation of the AMS axes with respect to dike margins (Féménias et al., 2004). The AMS investigation has been combined with thermomagnetic measurements to constrain the magnetic mineralogy, and with an image analysis in order to study the geometrical relationships between magnetic fabric and shape-preferred orientation of the rock-forming minerals. The results allow to constrain the tectonic and geodynamical contexts prevailing along the SW margin of Baltica (present-day orientation), during continental rifting prior to initiation of the Iapetus spreading.

\section{Geological setting}

The Egersund dike swarm crops out in the Proterozoic basement of SW Norway, a part of the Sveconorwegian orogen (Fig. 1a) that formed at 1.14-0.90 Ga (Bingen et al., 2008; Bogdanova et al., 2008) along the SW (present-day orientation) margin of Baltica (Scandinavia + Russia + Ukraine). The Sveconorwegian orogen is classically regarded as one of the several Grenvillian (s.l.) belts 


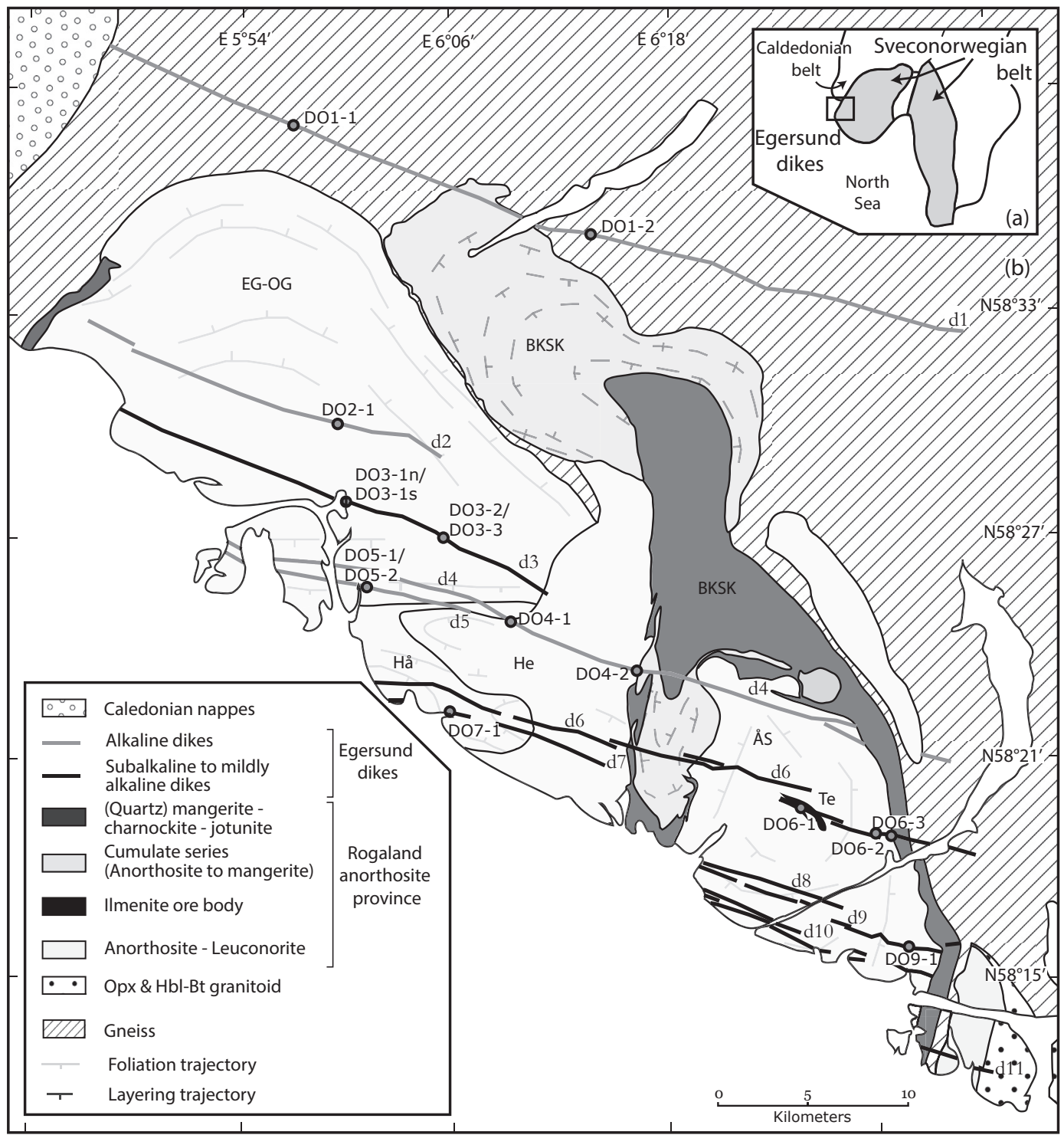

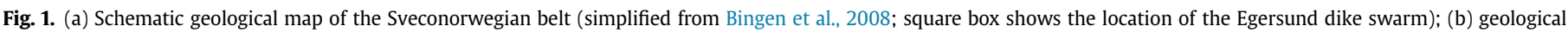

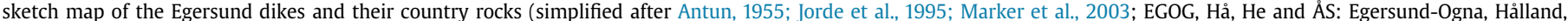

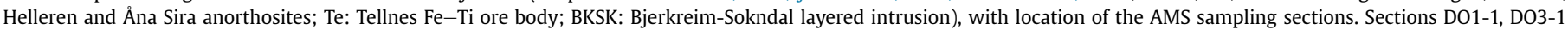

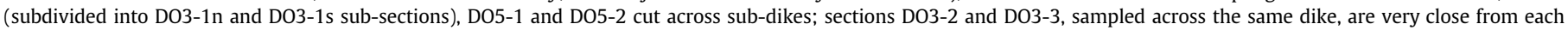
other and are therefore merged into a single point on the figure.

along which the assembly of the supercontinent Rodinia took place at $1 \mathrm{Ga}$ (e.g. Li et al., 2008). The Egersund dikes, emplaced well after the Grenvillian (s.l.) orogeny at $616 \pm 3 \mathrm{Ma}$ (baddeleyite U-Pb age; Bingen et al., 1998), reflect the last major magmatic event recorded in SW Norway. They have been interpreted as relating to a phase of continental rifting prior to opening of the Iapetus Ocean that marks the breakup of Rodinia (Torsvik et al., 1996; Bingen et al., 1998; Bingen and Demaiffe, 1999; Svenningsen, 2001).

Most dikes of the Egersund swarm cut across the 933-916 Ma (Schärer et al., 1996; Vander Auwera et al., 2011) Rogaland anorthosite province (Fig. 1b), a huge late-Sveconorwegian igneous complex that mainly consists of four coalescent intrusions (the Egersund-Ogna, Åna-Sira and Håland-Helleren anorthosites, and the Bjerkreim-Sokndal layered intrusion). Some dikes also intrude granulite-facies gneisses that form the country rocks of the anorthosite province. The swarm is hidden by the North See to the south, and by Caledonian nappes and Quaternary moraines to the west (Fig. 1b; Antun, 1955; Jorde et al., 1995).

\section{Field relationships, petrology and geochemistry}

According to Antun (1955), the Egersund dike swarm is made of eleven main dikes, that were labeled d1 to d11 from north to south (Fig. 1b). These dikes whose thickness varies from a few decimeters up to $30 \mathrm{~m}$ can be traced for some kilometers up to $60 \mathrm{~km}$. They are 4-5 km apart with the notable exception of dike d1. More recent field studies (Venhuis and Barton, 1986; Karlsen et al., 1998) indicate that many minor dikes are intercalated between the main dikes mapped by Antun (1955). All dikes have N110-120 ${ }^{\circ}$ E trends in average and steep (usually $\geq 70^{\circ}$ ) to vertical dips. Their dip directions do not vary along strike and SSW dips seem to dominate over NNW ones. Dikes are segmented, showing en-échelon arrangements and are locally divided into several sub-dikes (Fig. 1b; Antun, 1955; Karlsen et al., 1998). They commonly show finegrained to glassy margins. In dikes containing plagioclase phenocrysts (see below), the size and abundance of the phenocrysts decrease towards the margins along which a 1 - to $20-\mathrm{cm}$-wide 
zone almost devoid of phenocrysts occurs (Antun, 1955). Such a zoning reflects a mechanical segregation of early crystallized mineral phases away from the contacts as a consequence of shearing along dike rims induced by the flow of magma ("Bagnold effect"; Barrière, 1976; Komar, 1976).

The dikes can be divided into two groups according to their texture (Bingen et al., 1998; Bingen and Demaiffe, 1999): porphyritic with by townite phenocrysts (dikes $\mathrm{d} 3, \mathrm{~d} 7$ to $\mathrm{d} 11$ ) and aphyric (dikes d1-d2, d4 to d6). After Antun (1955), the porphyritic dikes are made of olivine dolerite, whereas the aphyric dikes consist of olivine trachy-dolerite, with the notable exception of dike d6 (dolerite sensu stricto). The porphyritic olivine dolerites (dikes d3, $\mathrm{d} 7$ to $\mathrm{d} 11$ ) and the aphyric dolerites (dike d6) define a single magmatic suite with a subalkaline to mildly alkaline basaltic signature, whereas the aphyric olivine trachy-dolerites (dikes d1d2, d4-d5) define a suite with an alkaline basaltic signature (Bingen and Demaiffe, 1999). According to the latter authors, these two distinct suites were derived from two slightly depleted asthenospheric mantle sources characterized by different $\mathrm{Sr}-\mathrm{Nd}$ isotope compositions, with parent magmas that probably ponded at the crust-mantle boundary $(\sim 1000 \mathrm{MPa})$ before intrusion at shallow level.

\section{Sampling strategy}

Fifteen sites were sampled for AMS measurements using a portable drill, along transversal sections across eight main dikes of the Egersund swarm (dikes $\mathrm{d} 1$ to $\mathrm{d} 7$ and $\mathrm{d} 9$, i.e. excluding $\mathrm{d} 8$ and d10-11; Figs. $1 \mathrm{~b}$ and 2). The AMS sections were named according to the dike nomenclature of Antun (1955), i.e. DO1-1 and DO1-2 for sections across dike $\mathrm{d} 1, \mathrm{DO} 2-1$ for dike $\mathrm{d} 2$, etc....

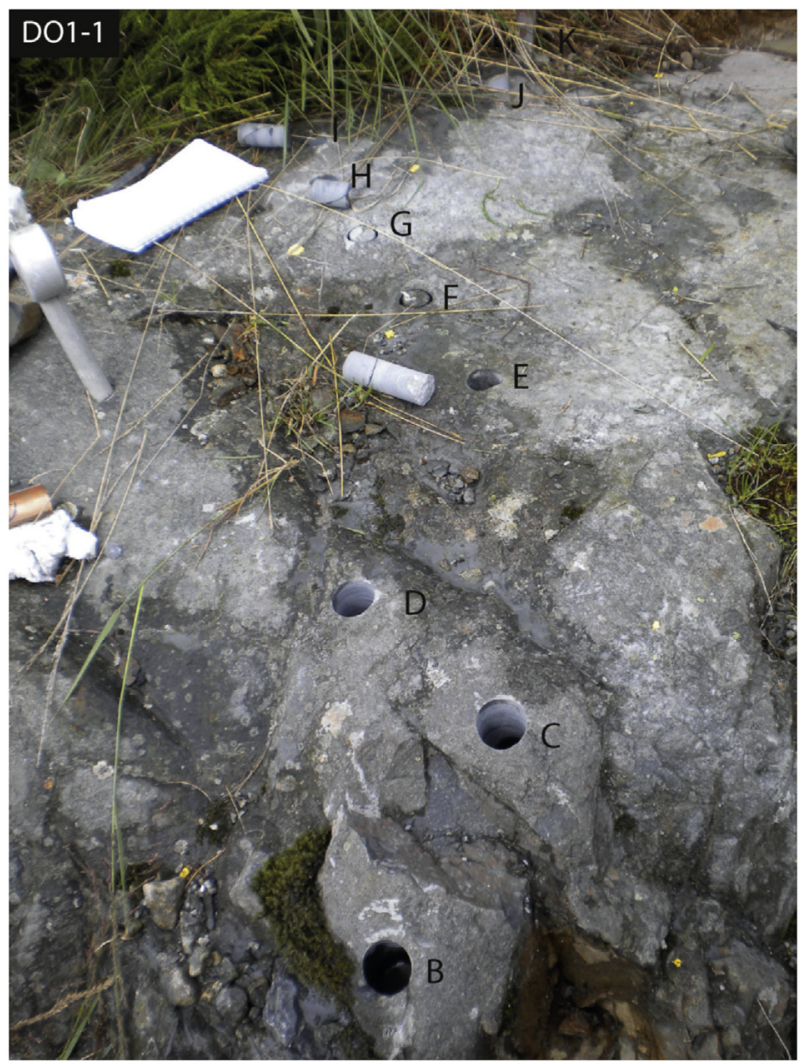

Fig. 2. Example of transversal AMS sampling section (D01-1; Fig. 1b for location). Letters refer to the emplacement of the core-drilled samples.
Most sampling sections are more or less complete, i.e. extend from one wall to the other. Among these sites, DO1-1, DO3-1, DO5-1 and D05-2 were sampled in sub-dikes: DO1-1 corresponds to a second-order sub-dike from a poorly-exposed portion of the large dike d1, DO3-1 combines two sub-sections (DO3-1n, " $n$ " for north and DO3-1s, "s" for south) cutting across two sub-dikes $\sim 1 \mathrm{~m}$ apart, and DO5-1 and D05-2 correspond, respectively, to a first- and a second-order sub-dike about $20 \mathrm{~m}$ apart. Since section DO3-2 was sampled at $\sim 12 \mathrm{~m}$ to the west of section DO3-3, across the same dike (d3), these two sections are not distinguished from each other on Fig. 1b. Some sections are partial (DO1-2, DO4-1, DO4-2, DO6-2 and DO6-3), i.e. start from one rim and cover only the adjacent dike material, the rest of the dike being hidden by vegetation or road surfacing. Sections DO6-2 and DO6-3, that belong to the less complete sections with regard to dike thickness are representative, respectively, of the southern and northern margins of two portions of the same dike (d6) that are about $530 \mathrm{~m}$ apart. The number of drilling stations (from 9 to 29) and the sampling interval along each section vary according to dike thickness and exposure conditions. A total of 21725 -mm-diameter orientated cores was collected.

These cores were cut into 676 22-mm-high cylinders in the laboratory (2-4 cylinders per core) for the AMS measurements and image analysis. Remaining core fragments were used to make thin and polished sections, and for the thermomagnetic measurements.

\section{Petrography}

Below is a synthetic petrographic description based on a transmitted and reflected light microscope study of our samples. More information on the petrography can be found in Antun (1955), Barton and van Bergen (1984), Venhuis and Barton (1986), Bingen et al. (1998), and Bingen and Demaiffe (1999).

Rocks outside the chilled margins are fine-grained (average grain sizes of a few hundreds of microns up to $1 \mathrm{~mm}$ ). They are mainly made of plagioclase, augite and olivine, and minor titanomagnetite and ilmenite, these oxides being more abundant in the aphyric olivine trachy-dolerites (alkaline suite) compared to the other occurrences. Titanomagnetite occurs as interstitial, subhedral to skeletal (Fig. 3a) grains, with a mean size of $\sim 200 \mu \mathrm{m}$. It usually contains lamellae of ilmenite resulting from an oxidationexsolution (oxy-exsolution) phenomenon (Fig. 3a, b; McEnroe and Brown, 2000; Dunlop and Özdemir, 2009). Ilmenite forms both interstitial subhedral grains and amoeboid to very skeletal (Fig. 3c) individuals intimately associated with the silicate matrix. In the porphyritic dikes, euhedral to subhedral phenocrysts of plagioclase (mean length of $\sim 1 \mathrm{~cm}$ ) are set in a subophitic matrix (Fig. 4a). In the aphyric dikes, the texture is also subophitic (Fig. 4b). Sulfides (pyrrhotite, pyrite, chalcopyrite, pentlandite), apatite, biotite, K-feldspar and quartz are accessories.

In the chilled margins, euhedral microphenocrysts of plagioclase ( \pm augite \pm olivine \pm oxides) are set in a very fined-grained to glassy matrix. The plagioclase microphenocrysts display commonly a well-expressed shape-preferred orientation resulting from magma shearing along dike walls (Fig. 4c). A similar texture defined by plagioclase phenocrysts is locally visible macroscopically. Microstructures indicating a weak near- or subsolidus ductile deformation are sporadically observed, mostly in plagioclase phenocrysts from the central part of the dikes that exhibit locally undulose extinction and bending of the polysynthetic twins.

Most dikes have been affected by hydrothermal alteration during prehnite-pumpellyite metamorphism related to Caledonian overthrusting (Barton and van Bergen, 1984; Venhuis and Barton, 1986). This alteration (Fig. 4d) is particularly intense in the center of dike $\mathrm{d} 6$ (section DO6-1) and at the rims of dike $\mathrm{d} 1$ (sections DO11 and D01-2). Weathering produced varied secondary species, 

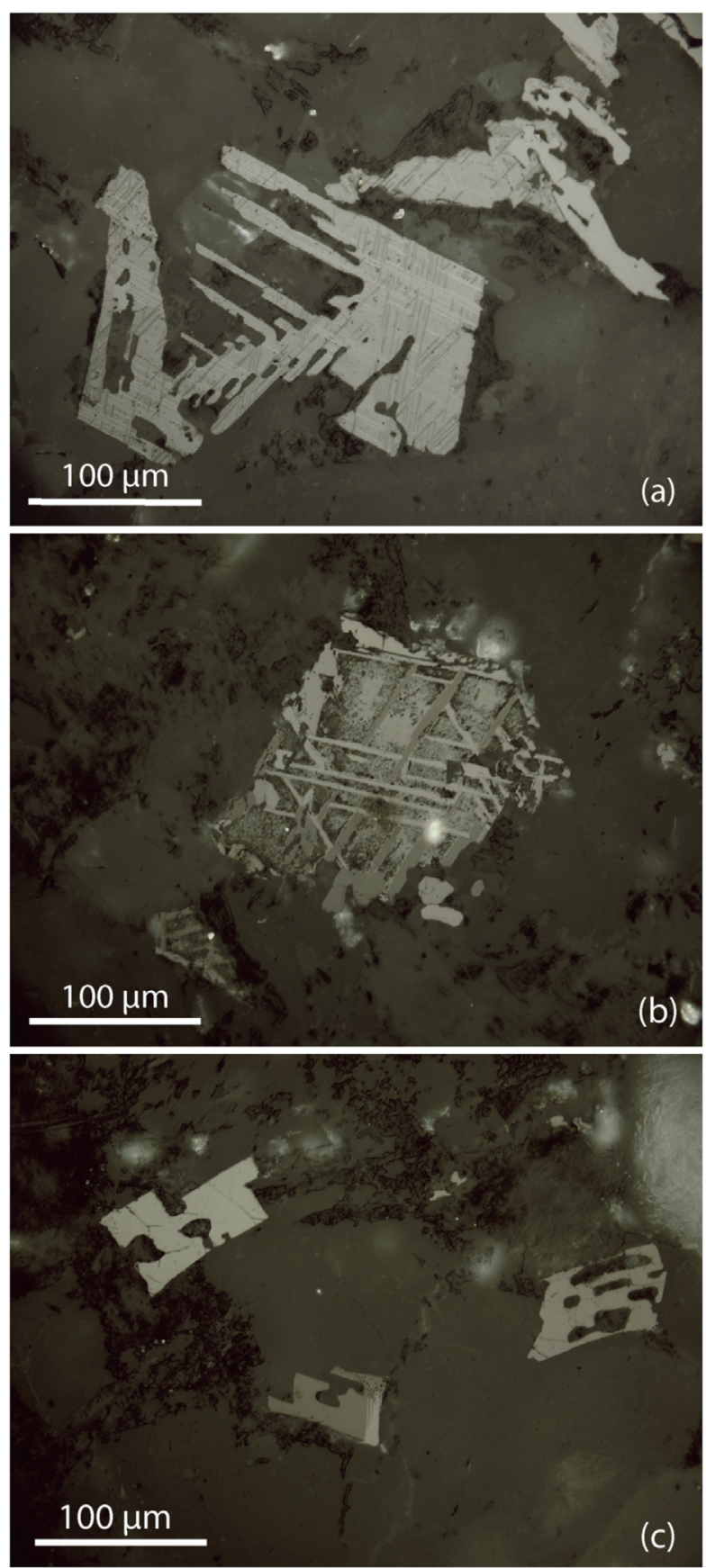

Fig. 3. Reflected-light photomicrographs. (a) skeletal titanomagnetite grain displaying very thin oxidation-exsolution lamellae of ilmenite (sample D01-1I); (b) oxidized titanomagnetite (magnetite-rich areas between sandwich lamellae of ilmenite are replaced by a fine-grained opaque phase, likely maghemite; sample D01-2B); (c) skeletal ilmenite grains associated with plagioclase (sample DO3-1Z).

including some magnetite from the silicates, leucoxene from ilmenite and a fine-grained opaque phase from the magnetite-rich areas between the ilmenite lamellae in titanomagnetite grains (Fig. 3b). The latter secondary fine-grained opaque is likely maghemite, a classic alteration product of magnetite in doleritic dikes (e.g. McEnroe and Brown, 2000; Silva et al., 2010).

\section{Thermomagnetic curves}

Thermomagnetic measurements (magnetic susceptibility vs. temperature) were performed in air, on crushed rocks, using a CS3 apparatus coupled with a KLY-4S Kappabridge instrument (AGICO Inc.). Specimens were progressively heated from room temperature up to $680^{\circ} \mathrm{C}$ and subsequently cooled. The experiments were carried out on five selected AMS samples from dikes belonging to the two magmatic suites (D01-1I, DO2-1I, DO3-3S, D04-2K, DO9-1G). Their bulk susceptibility values, as calculated from the AMS data presented below, are representative of the entire sample set.

Evolution of the heating curves (Fig. 5) reveals a negligible contribution of the paramagnetic minerals (augite, olivine, ilmenite), with the notable exception of the low susceptibility sample D09-1G whose susceptibility during heating decreases between room temperature and $\sim 335^{\circ} \mathrm{C}$. All heating curves, except maybe D09-1G, display a faint Hopkinson peak at $\sim 545-560{ }^{\circ} \mathrm{C}$, followed by a steep decay indicative of a Curie temperature close to $580^{\circ} \mathrm{C}$. The predominant magnetic carrier has thus a composition close to pure magnetite, confirming the thermomagnetic analysis of Walderhaug et al. (2007). This ferromagnetic phase corresponds to the titanomagnetite grains observed in all samples, with a probably small additional contribution of the secondary magnetite grains evidenced in some samples. The abundant ilmenite lamellae observed in the titanomagnetite grains account for the near-endmember composition (segregation between magnetite-rich areas and ilmenite lamellae related to Ti diffusion during oxy-exsolution; McEnroe and Brown, 2000; Dunlop and Özdemir, 2009). The slight inflection point or hump observed in some curves (D01-1I, DO2-1I, D04-2K) at $\sim 390-400{ }^{\circ} \mathrm{C}$ (Fig. 5a, b, d) is ascribed to inversion into hematite of the secondary maghemite.

The cooling curves of samples DO3-3S and D09-1G display a strongly irreversible behavior due to an important increase in susceptibility (Fig. 5c, e) resulting from the formation of a high susceptibility mineral at high-T, probably magnetite coming from the breakdown of $\mathrm{Fe}-\mathrm{Mg}$ minerals. The nearly-reversible curve of sample DO4-2K (Fig. 5d) and the slightly lower susceptibility values of the cooling curve are attributed to hematitization at high-T of maghemite. By comparison to the latter samples, the case of D01-1I and DO2-1I display intermediate behaviors (Fig. 5a, b).

\section{Magnetic fabric}

The orientation and length of the three principal, mutually orthogonal axes of the AMS ellipsoid $\left(K_{1} \geq K_{2} \geq K_{3}\right)$ were measured (using the small cylinders cut from the orientated drilled cores) in a low magnetic field, with a Kappabridge KLY-3 susceptometer (AGICO Inc.; sensitivity of $2 \times 10^{-8} \mathrm{SI}$ ). For each drilling station, an average ellipsoid was calculated using the method of Hext (1963). The complete set of AMS data is presented in Appendix A and average AMS data for the fifteen sampling sections are given in Table 1.

\subsection{Scalar parameters}

The bulk magnetic susceptibility $K_{m}$, given by the arithmetic mean of $K_{1}, K_{2}$ and $K_{3}$, ranges from 0.69 to $63.3 \mathrm{mSI}$ (Appendix A) with an average of $30.2 \mathrm{mSI}$. Values are independent of dike thickness and are distinctly higher in the alkaline suite than in the subalkaline to mildly alkaline suite (Table 1 ; Fig. $6 a$ ): $K_{m}$ ranges from 13.0 to $63.3 \mathrm{mSI}$ in dikes d1-2 and d4-5 (alkaline suite), with mean values of $36.2 \mathrm{mSI}(\mathrm{d} 1), 53.1 \mathrm{mSI}(\mathrm{d} 2), 37.5 \mathrm{mSI}(\mathrm{d} 4)$ and $41.8 \mathrm{mSI}$ (d5), whereas $K_{m}$ values range from 0.69 to $25.2 \mathrm{mSI}$ in dikes d3, d6-7 and d9 (subalkaline to mildly alkaline suite), with averages of $15.2 \mathrm{mSI}(\mathrm{d} 3), 14.8 \mathrm{mSI}$ (d6), $9.3 \mathrm{mSI}(\mathrm{d} 7)$ and $3.1 \mathrm{mSI}$ 

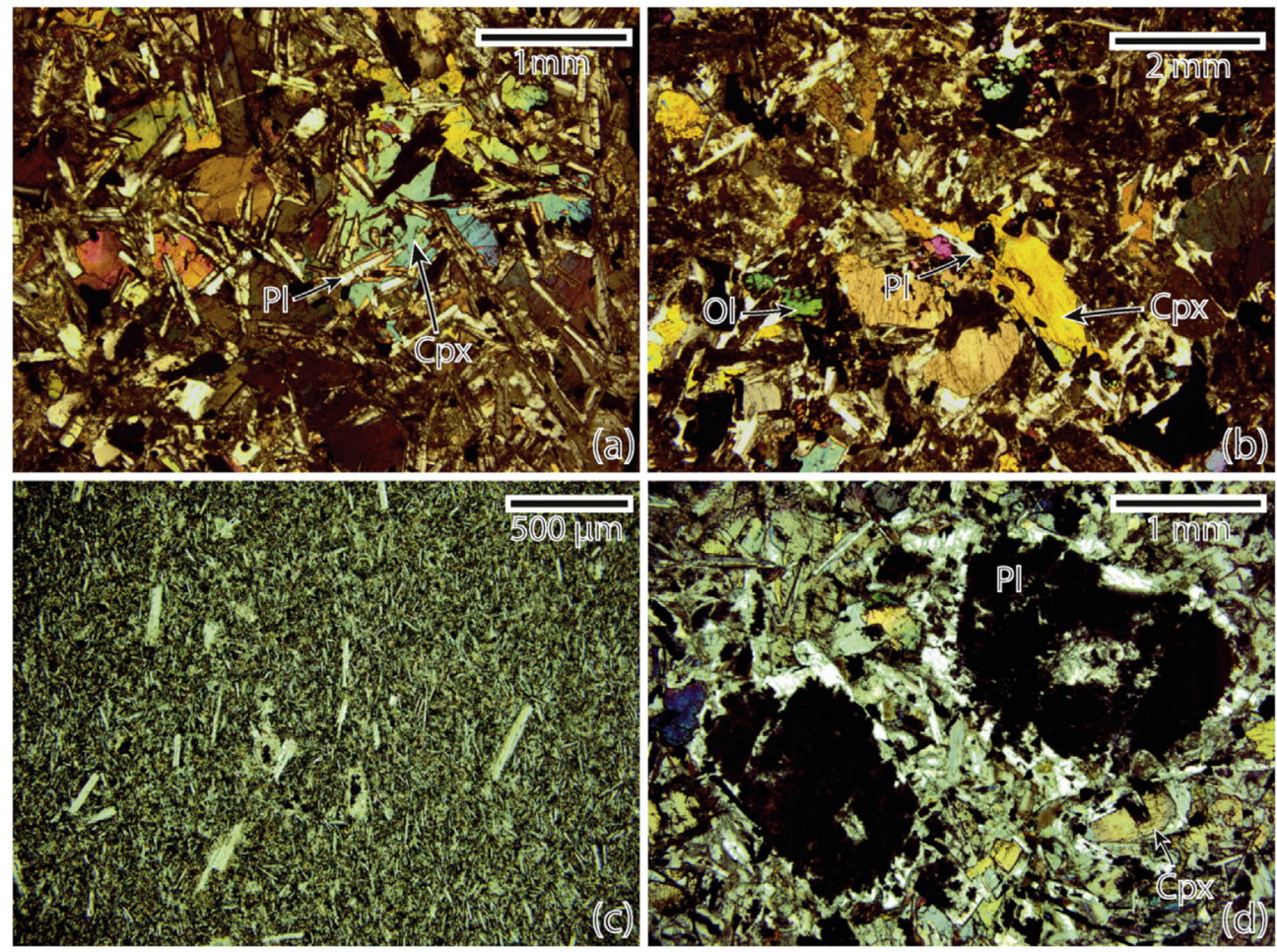

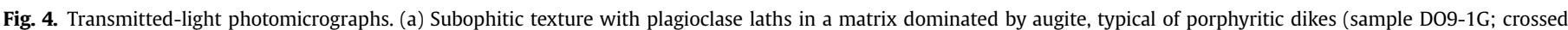

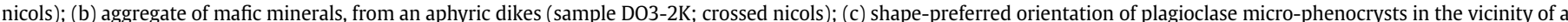
dike wall (sample D06-1A; uncrossed nicols); (d) altered plagioclase phenocrysts (sample DO7-1M; crossed nicols). Pl: plagioclase; Cpx: clinopyroxene; Ol: olivine.

(d9). Such a dichotomy between the two suites finds expression in a well-defined bimodal distribution in the histogram of $K_{m}$ (Fig. 6b).

The $K_{m}$ values (>0.5 mSI) are weakly to strongly "ferromagnetic" (in the sense given by Bouchez, 2000 for granites), in agreement with the thermomagnetic data pointing to the presence of Ti-poor, thus ferromagnetic titanomagnetite. Samples having the largest paramagnetic contributions are found in the low-susceptibility dikes from the subalkaline to mildly alkaline suite (dikes d3, d6-7, d9; Appendix A). These samples represents approximately $10 \%$ of the sampling stations. The strong influence of Ti-poor titanomagnetite on the magnetic mineralogy provides a simple explanation for the $K_{m}$ values displayed by the two magmatic suites: the aphyric olivine trachy-dolerites (alkaline suite) are richer in oxides, including titanomagnetite, as revealed by the optical observations and, hence, have higher susceptibilities.

The $P_{j}$ and $T_{j}$ parameters of Jelínek (1981), that help to quantify the anisotropy degree and shape of the magnetic fabric respectively, are given by:

$$
\begin{aligned}
& P_{\mathrm{j}}=\exp \sqrt{2 \sum_{\mathrm{i}}\left(\ln K_{\mathrm{i}} / K_{\mathrm{m}}\right)^{2}}(i=1 \text { to } 3) \text { and } \\
& T_{\mathrm{j}}=\left(2 \ln K_{2}-\ln K_{1}-\ln K_{3}\right) /\left(\ln K_{1}-\ln K_{3}\right)
\end{aligned}
$$

$P_{j}$ expresses the eccentricity of the AMS ellipsoid and varies from 1 (spherical ellipsoid) to infinity. $T_{j}$ reflects the shape of the AMS ellipsoid and allows to distinguish between oblate $\left(0<T_{j} \leq+1\right)$, neutral $\left(T_{j}=0\right)$ and prolate $\left(-1 \leq T_{j}<0\right)$ ellipsoids. The low $P_{j}$ values in the Egersund swarm, ranging from 1.003 to 1.073 (Appendix A), indicate weakly anisotropic magnetic fabrics. Values of $T_{j}$ vary from -0.848 to $0.973,66 \%$ of the data being positive (Appendix A). As a consequence, the magnetic fabrics range from strongly prolate, through neutral, to strongly oblate, with a slight domination of the oblate shapes. $P_{j} v s . K_{m}$ and $T_{j} v s . P_{j}$ diagrams drawn for average values (Fig. 7) show that sections sampled across the same dike frequently have quite similar mean $K_{m}, P_{j}$ and $T_{j}$ parameters. Since these sections correspond to dike portions that may be several kilometers apart, it is concluded that, in average, the proportion of magnetic minerals (in particular, titanomagnetite) as well as the strength and shape of the magnetic fabric are rather constant or vary progressively along dike strike. The only exception concerns sections D01-1 and DO1-2 (dike d1) that have similar average $K_{m}$ and $P_{j}$ values, but distinct average $T_{j}$ values ( $-0.196 v s$. 0.761 , respectively; Table 1). Fig. 7 shows also that sections DO4-1, DO4-2, DO5-1 and D05-2, sampled in the center of the swarm, are characterized by peak values of the average anisotropy degree ( $z$ 1.035) and moderately to strongly oblate mean-AMS ellipsoids (average $T_{j} \gtrsim 0.50$ ).

Transversal variation profiles of $K_{m}, P_{j}$ and $T_{j}$ are displayed in Fig. 8a. Many profiles reveal a well-defined decrease of $K_{m}$ near the dike margins. Similar rim-to-rim evolutions of the bulk magnetic susceptibility are commonly observed in magnetic studies conducted along transversal sections of dikes (Walderhaug, 1993; Féménias et al., 2004; Creixell et al., 2006; Silva et al., 2010). The occurrence of susceptibility minima at dike margins can result from several, not-mutually exclusive causes: (1) diminution of the modal proportions of magnetic minerals due to either Bagnold effect (Féménias et al., 2004) or rapid cooling hindering late crystallization of interstitial phases such as (titano)magnetite (Park et al., 1988), (2) chemical variation (Ti-enrichment possibly promoted by a lower degree of oxy-exsolution compared to dike core) and/or grain-size reduction of (titano)magnetite (Walderhaug, 1993; Silva et al., 2010), and (3) weathering due to late-emplacement fluid percolation (Féménias et al., 2004; Silva et al., 2010). The latter cause has probably only a weak influence on the $K_{m}$ profiles in the present case. Indeed, the susceptibility minima observed at the 

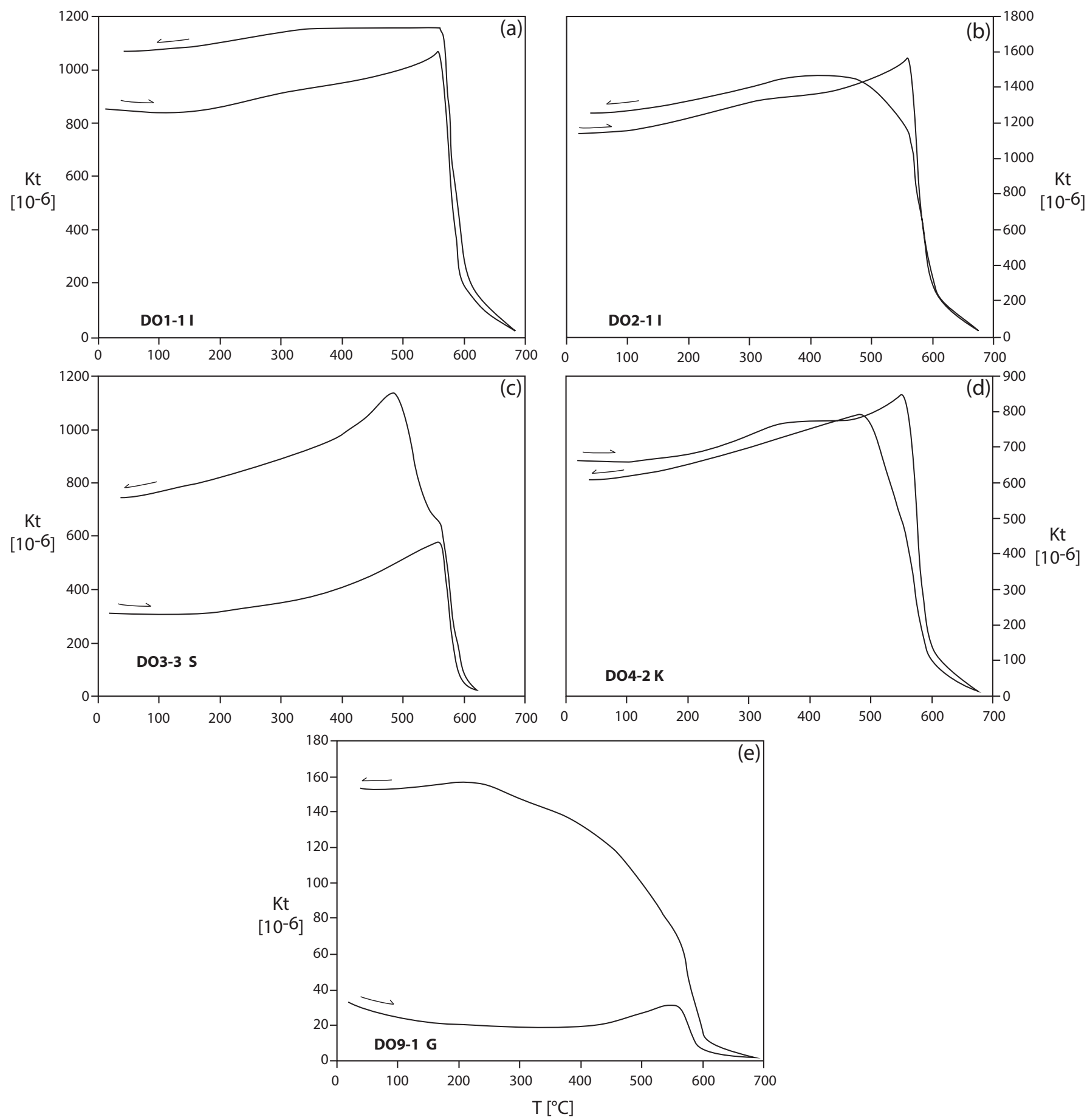

Fig. 5. Thermomagnetic curves (K vs. T) for samples from the alkaline suite (DO1-1I, DO2-1I and DO4-2K) and the subalkaline to mildly alkaline suite (DO3-3S and D09-1G).

margins of dike d1 for sections D01-1 and D01-2 are correlated with a strong hydrothermal alteration; however, such a correlation is not observed for the other minima and the strong alteration in the center of section D06-1 does not produce any drop of $K_{m}$ (Fig. 8a).

$P_{j}$ profiles (Fig. 8a) show two opposite evolutions towards dike rims: either a decrease, usually positively correlated with $K_{m}$ (sections DO3-1n, DO3-1s, DO3-3 (N rim), DO4-1, DO5-2 (N rim), D06-1, D06-2, DO6-3 and D09-1) or an increase, usually negatively correlated with $K_{m}$ (sections DO1-1, DO1-2, DO2-1, DO3-3 (S rim), D04-2, DO5-1 and D07-1). $P_{j}$ remains rather constant when approaching the southern dike margin for sections DO3-2 and D05-2, whereas in both cases, the $K_{m}$ values display a spectacular decrease. A decrease of $P_{j}$ at dike rims, correlated with a decrease of $K_{m}$, has been described in mafic dikes from the Motru swarm (Romania) by Féménias et al. (2004) and interpreted as reflecting a weakly anisotropic magmatic fabric along dike margins. According to the latter authors, this situation is possibly related to (1) a variation in magma rheology due to the Bagnold effect, with a crystal-rich magma in the dike core and a crystal-free magma at the rim (hence closer to isotropy) and/or (2) a high shear rate at dike margin, producing a low-intensity fabric according to the 
Table 1

Geometry of the dikes at the sampling sites and average AMS data.

\begin{tabular}{|c|c|c|c|c|c|c|c|c|c|c|c|c|c|}
\hline \multirow[t]{2}{*}{ Dike } & \multirow[t]{2}{*}{ AMS section } & \multirow[t]{2}{*}{ Coord. } & \multirow[t]{2}{*}{ Thickness (m) } & \multirow[t]{2}{*}{ Orientation } & \multirow[t]{2}{*}{$\mathrm{N}$} & \multirow[t]{2}{*}{$\mathrm{K}_{\mathrm{m}}$} & \multirow[t]{2}{*}{$\mathrm{K}_{\mathrm{m}}$ (dike average) } & \multirow[t]{2}{*}{$P_{j}$} & \multirow[t]{2}{*}{$\mathrm{T}_{\mathrm{j}}$} & \multicolumn{2}{|l|}{$\mathrm{K}_{1}$} & \multicolumn{2}{|l|}{$\mathrm{K}_{3}$} \\
\hline & & & & & & & & & & Dec. & Inc. & Dec. & Inc. \\
\hline \multirow{2}{*}{$\mathrm{d} 1(\mathrm{Ap} A)$} & D01-1 & $22250 / 05090$ & 1.8 & $\mathrm{~N} 130^{\circ} \mathrm{E} / 82^{\circ} \mathrm{SW}$ & 10 & 41 & 36.2 & 1.013 & -0.196 & 172 & 77 & 353 & 13 \\
\hline & D01-2 & $37830 / 99090$ & $\sim 22.5$ & $\mathrm{~N} 100^{\circ} \mathrm{E} / 70^{\circ} \mathrm{S}$ & 12 & 31.1 & & 1.011 & 0.761 & 98 & 17 & 360 & 24 \\
\hline d2 (Ap A) & DO2-1 & $24350 / 89130$ & 5.8 & $\mathrm{~N} 103^{\circ} \mathrm{E} / 75^{\circ} \mathrm{S}$ & 11 & 53.1 & 53.1 & 1.015 & -0.19 & 332 & 3 & 63 & 24 \\
\hline \multirow[t]{4}{*}{ d3 (Pp S) } & DO3-1n & $24860 / 84990$ & 1.2 & $\mathrm{~N} 112^{\circ} \mathrm{E} / 84^{\circ} \mathrm{SW}$ & 12 & 14.1 & 15.2 & 1.024 & -0.133 & 181 & 5 & 272 & 12 \\
\hline & DO3-1s & & 2.3 & $\mathrm{~N} 120^{\circ} \mathrm{E} / 83^{\circ} \mathrm{SW}$ & 17 & 10.6 & & 1.039 & 0.121 & 182 & 7 & 92 & 1 \\
\hline & DO3-2 & $30020 / 83060$ & $\sim 1.2$ & $\mathrm{~N} 120^{\circ} \mathrm{E} / 80^{\circ} \mathrm{S}$ & 12 & 16.1 & & 1.02 & 0.317 & 280 & 66 & 76 & 22 \\
\hline & DO3-3 & $30030 / 83050$ & $\sim 3$ & $\mathrm{~N} 110^{\circ} \mathrm{E}$ & 20 & 20.2 & & 1.026 & 0.216 & 297 & 55 & 37 & 7 \\
\hline \multirow[t]{2}{*}{$\mathrm{d} 4(\mathrm{Ap} A)$} & DO4-1 & $33480 / 78710$ & $>1.60$ & $\mathrm{~N} 100^{\circ} \mathrm{E} / 80^{\circ} \mathrm{S}$ & 12 & 38.8 & 37.5 & 1.034 & 0.487 & 215 & 75 & 16 & 14 \\
\hline & DO4-2 & $40090 / 76110$ & $>12$ & $\mathrm{~N} 111^{\circ} \mathrm{E} / 79^{\circ} \mathrm{S}$ & 14 & 36.3 & & 1.045 & 0.537 & 115 & 23 & 22 & 8 \\
\hline \multirow[t]{2}{*}{ d5 (Ap A) } & DO5-1 & $26130 / 80420$ & 6 & $\mathrm{~N} 105^{\circ} \mathrm{E} / 69^{\circ} \mathrm{N}$ & 24 & 44.3 & 41.8 & 1.069 & 0.913 & 293 & 20 & 197 & 18 \\
\hline & DO5-2 & & 0.5 & $\mathrm{~N} 100^{\circ} \mathrm{E} / 77^{\circ} \mathrm{N}$ & 9 & 34.2 & & 1.066 & 0.539 & 294 & 13 & 200 & 16 \\
\hline \multirow[t]{3}{*}{ d6 (Ap S) } & D06-1 & $48610 / 69030$ & 7.5 & $\mathrm{~N} 107^{\circ} \mathrm{E} / 90^{\circ}$ & 21 & 14.3 & 14.8 & 1.007 & -0.202 & 37 & 33 & 265 & 46 \\
\hline & D06-2 & $53820 / 67450$ & $>18$ & $\mathrm{~N} 95^{\circ} \mathrm{E} / 87^{\circ} \mathrm{S}$ & 6 & 16.8 & & 1.027 & -0.623 & 333 & 3 & 69 & 61 \\
\hline & DO6-3 & $53290 / 67460$ & 18 & $\mathrm{~N} 77^{\circ} \mathrm{E} / 82^{\circ} \mathrm{N}$ & 5 & 14.3 & & 1.02 & -0.637 & 152 & 6 & 39 & 74 \\
\hline d7 (Pp S) & DO7-1 & $30740 / 73920$ & 4.3 & $\mathrm{~N} 107^{\circ} \mathrm{E} / 90^{\circ}$ & 17 & 9.3 & 9.3 & 1.015 & 0.604 & 141 & 20 & 240 & 22 \\
\hline d9 (Pp S) & D09-1 & $54460 / 61520$ & $\sim 5$ & $\mathrm{~N} 115^{\circ} \mathrm{E}^{*}$ & 12 & 3.1 & 3.1 & 1.012 & -0.355 & 349 & 21 & 84 & 13 \\
\hline
\end{tabular}

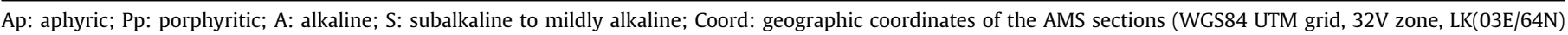

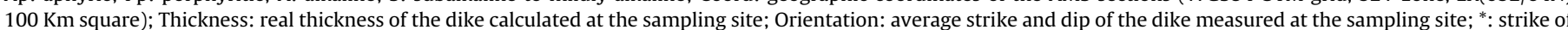

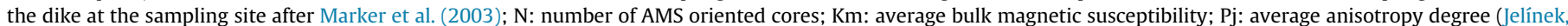
1981); Tj: average shape parameter (Jelínek, 1981); Dec and Inc: declination and inclination of the AMS axes.

experiments of Arbaret et al. (1996, 2000, 2001) in which deformation rate and magmatic fabric anisotropy are negatively correlated. In the Egersund swarm, low $P_{j}$ values at dike margins are commonly associated with a strong shape fabric of plagioclase laths (e.g. ends of section DO6-1 at the margins of dike d6; Fig. 4c; Fig. 8a). Hence, assuming that the magnetic fabric fits the plagioclase shape fabric (this is checked below) the explanation provided by Féménias et al. (2004) for low $P_{j}$ values along dike rims does not stand here. Actually, the strength of a magnetic fabric is not necessarily a proxy for the intensity of the finite strain undergone by the rock. It also depends on the mineralogical composition (Rochette et al., 1992). The decrease of $P_{j}$ and $K_{m}$, observed in many sections simply reflects the increase in the paramagnetic contribution (due to silicates) for which the anisotropy degree is much lower than the titanomagnetite for the same finite strain undergone by the rock. Such a correlation is commonly observed in ferromagnetic rocks (see examples in Rochette et al., 1992 and Bouchez, 2000). The increase of $P_{j}$, as observed at dike rims for a number of sections is attributed to shearing along dike walls.

The $T_{j}$ profiles (Fig. 8a) are commonly rather irregular, passing rapidly from positive to negative values (oblate to prolate AMS ellipsoids), except for sections DO4-1, DO4-2, DO5-1 and DO5-2 for which $T_{j}$ remains distinctly positive and locally reaches values slightly higher or lower than 0 (neutral AMS ellipsoids). The evolution of $T_{j}$ towards dike margins is rather variable from one case to the other. As a consequence, no systematic correlation can be defined between the transversal evolution of $T_{j}$, and those of $P_{j}$ and $K_{m}$.

\subsection{Directional data}

The magnetic fabric across dikes is usually quite homogeneously distributed, as shown in particular by the regular patterns drawn by the magnetic foliation ( $K_{1} K_{2}$ plane) and the lineation ( $K_{1}$ axis) along the sampling sections (Fig. $8 \mathrm{~b}$ ), and by clustering of the AMS axes in Schmidt plots (Fig. 9). Most AMS sections are characterized by a progressive transversal variation of the magnetic fabric orientation, with foliation strikes and lineation trends at low angle or subparallel to the dike walls near the rims and progressively rotating towards higher angles away from the contacts (Fig. 8b). It can be seen from the most complete sections that these transversal variations lead to asymmetrical, sigmoidal arrangements of the magnetic foliations and lineations with regard to dike plane, as seen in map view (Figs. 8b, 10a and 11a).

Some sections display peculiar sigmoidal distributions of the magnetic fabric (Figs. 8b, 10a and 11a): (1) sigmoidal trajectories are strongly asymmetrical in sections DO3-1s and DO3-1n, with strikes that tend to parallel the southern margin, but keep a highly oblique orientation near the northern wall, whereas sigmoidal trajectories are more or less symmetrical for other most complete AMS sections (see Fig. 10c for the definition of asymmetrical vs. symmetrical sigmoidal trajectories); (2) a "nested" sigmoidal arrangement of the magnetic fabric is observed for sections DO7-1 and D09-1, lineation and foliation strike being subparallel to dike plane close to the rims and in the center of the dike, and being highly oblique to subperpendicular in between (the "nested" pattern is responsible for the large, partly overlaping confidence cones in the equal-area plot of section D09-1; Fig. 9); and (3) the foliation and lineation trends are slightly oblique to subparallel to dike plane in sections DO4-2, D05-1 and DO5-2 (plus DO4-1 for the foliations only), giving rise to weakly-asymmetrical patterns. It is worth to note that the latter four sections have quite high average $P_{j}$ values, along with oblate mean-AMS ellipsoids (Table 1; Fig. 7).

Perturbations of the homogeneous patterns drawn by the magnetic fabric occur locally, commonly, but not systematically, in the marginal areas of the dikes (Fig. 8b): (1) some samples have their magnetic foliations and lineations oblique with respect to neighboring drilling stations. These "erratic" magnetic fabrics are mostly found in the strongly-altered, southern marginal portion of D01-1 and D01-2, and central zone of DO6-1. The relative abundance of erratic magnetic fabrics in sections DO1-1, D01-2 and D06-1, compared to the number of sampling stations, explains the quite dispersed equal-area plots for these sections (Fig. 9); (2) erratic magnetic foliations or lineations due to inverted $K_{2}$ and $K_{3}$ axes or $K_{1}$ and $K_{2}$ axes occur also. Some of these obliquities are correlated to weathering, others seem to express strongly prolate or strongly oblate magnetic fabric (e.g. in section DO5-1, divergent magnetic lineations due to inversion between $K_{1}$ and $K_{2}$ are numerous in the northern part of the dyke characterized by $T_{j}$ values $\gtrsim 0.80$; Fig. 8). Image analysis (see Section 8) will confirm the influence of hydrothermal alteration on the magnetic fabric.

When the orientation of the average magnetic fabric is 

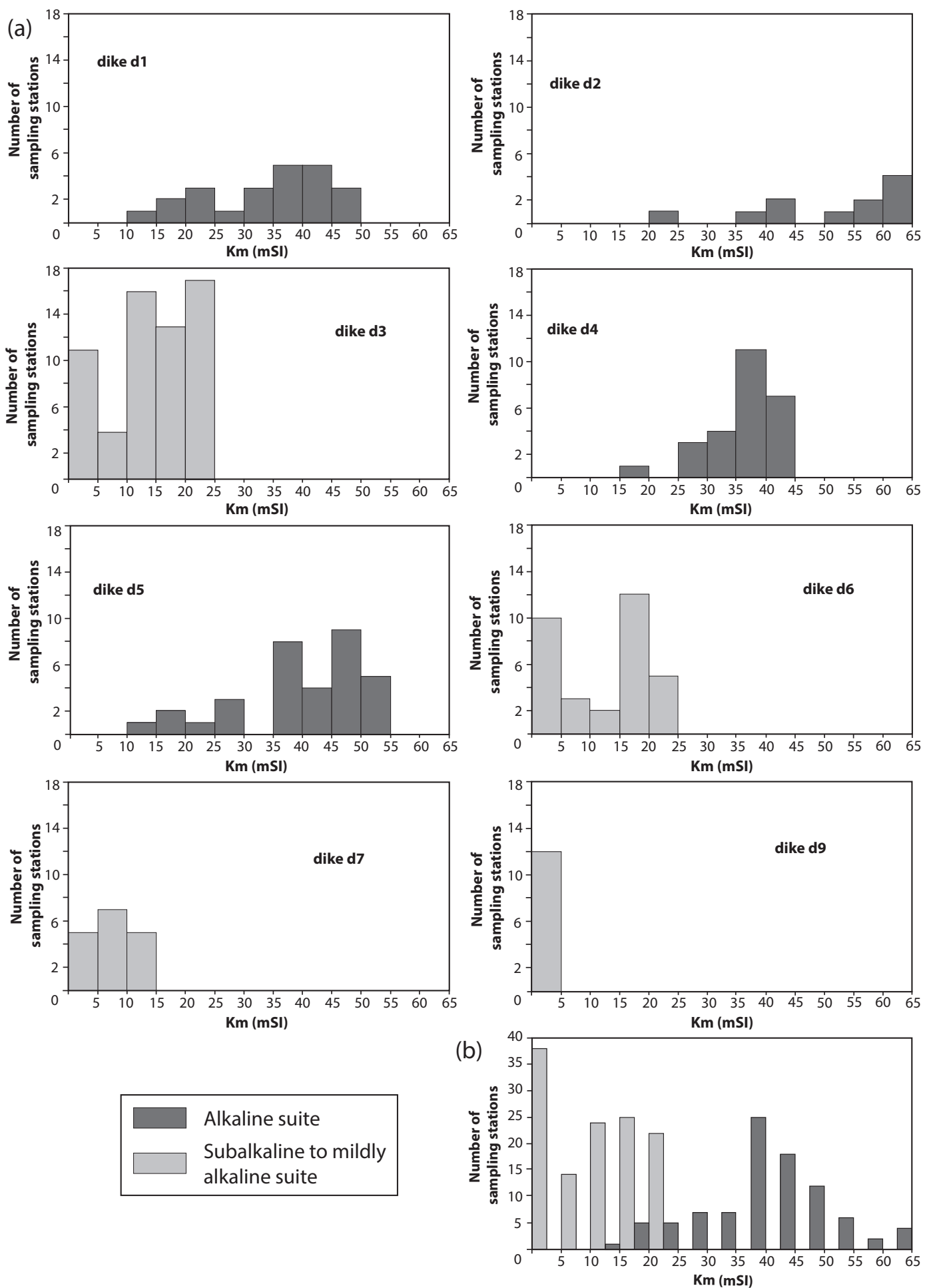

Fig. 6. Histograms of the bulk magnetic susceptibility $\left(K_{m}\right)$. (a) For the eight sampled dikes; (b) Synthetic histogram for the whole AMS data set.

compared to the average dike plane, disregarding AMS sections DO3-3 and D09-1 for which dike orientation is fixed only by its strike, it appears that five out of fourteen sections (D01-2, DO4-1, D04-2, DO5-1 and DO5-2) have a mean magnetic foliation at very low angle $\left(\leq 10^{\circ}\right)$ with the dike plane, the other sections displaying a moderately to strongly oblique mean magnetic foliation (angle ranging from $46^{\circ}$ to $88^{\circ}$; Table 1 ; Fig. 10a). The mean magnetic lineation is subparallel to the average dike plane (angle $\leq 10^{\circ}$ ) for
D01-1, D03-2 and all AMS sections that show a low angle between mean magnetic foliation and dike plane. For the other sections, the angle between lineation and dike plane varies from $32^{\circ}$ to $75^{\circ}$. The average magnetic foliations and lineations and, thus, the angle they make with the dike plane are strongly dependent on: (1) the transversal variation of the magnetic fabric orientation (shape of trajectory; e.g. the angle is very low for DO4-1, DO4-2, DO5-1, DO52 , but $\sim 60-70^{\circ}$ for DO3- $1 \mathrm{n}, \mathrm{DO} 3-1 \mathrm{~s}$ whose trajectories are strongly 

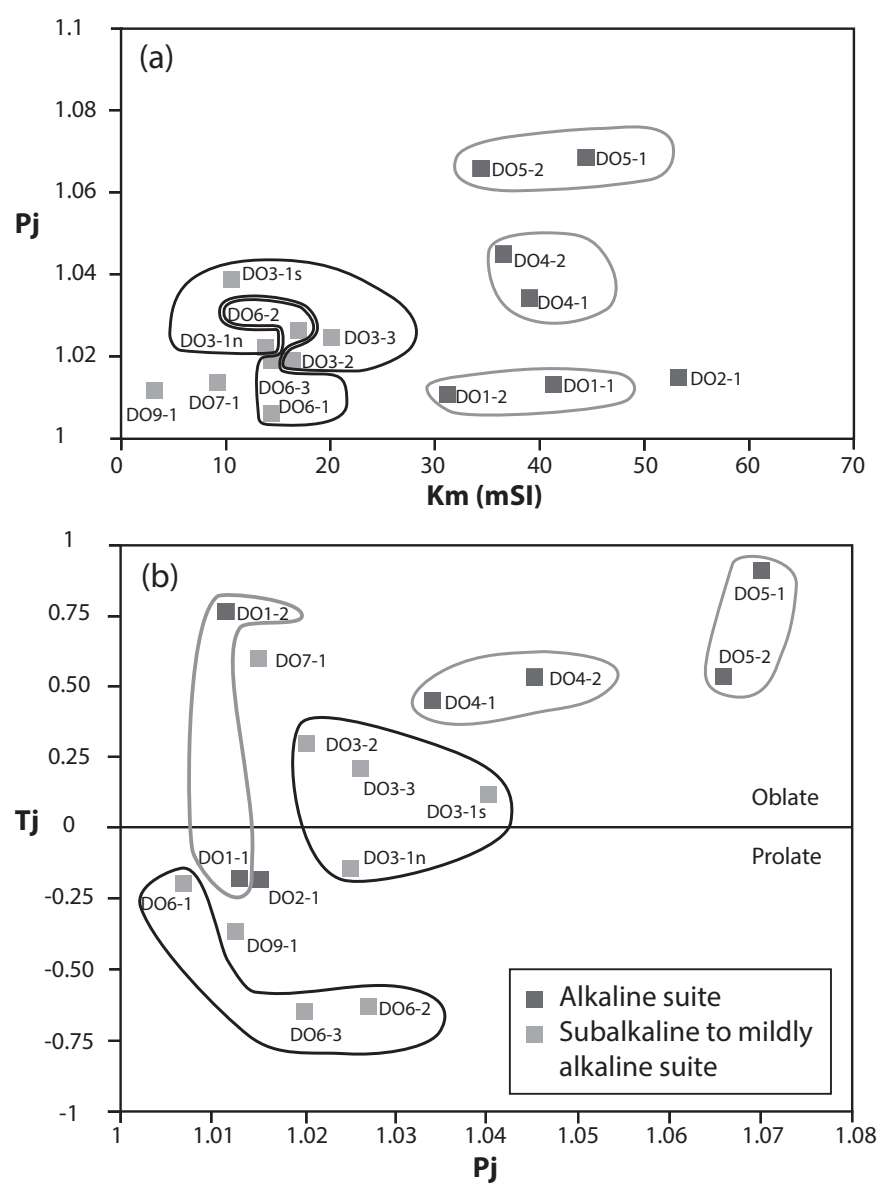

Fig. 7. Variation diagrams for $K_{m}, P_{j}$ and $T_{j}$ average values. (a) Plot of $P_{j} v s . K_{m}$; (b) plot of $T_{j}$ vs. $P_{j}$.

oblique to dike trend); (2) the complete $v$ s. partial status of the sampling sections (e.g. DO6-2 and D06-3 are very partial sections and display very high angles of $\sim 60-90^{\circ}$ ); and (3) the abundance of erratic fabrics (DO6-1 in particular).

The average plunge of the magnetic lineations is rather variable $\left(3^{\circ}-77^{\circ}\right)$ and not related to consistent directions (Table 1; Fig. 11b). It reveals two groups of AMS sections indistinctly covering dikes from the two magmatic suites (Fig. 11c): one dominant group with low plunges of $K_{1}$ (from $3^{\circ}$ to $23^{\circ}$; Table 1 ) and one subordinate group with moderate to high plunges (DO1-1, D03-2, DO3-3, DO41 and DO6-1; from $33^{\circ}$ to $77^{\circ}$; Table 1 ). The former group includes some peculiar cases displaying quite numerous moderately-to steeply-plunging lineations (Fig. 8b), namely DO3-1n and DO3-1s (close to dike margins), and DO1-2 (disregarding the erratic magnetic fabrics from the southern marginal portion).

\section{Relationship between the magnetic fabric and the petrofabric}

The AMS of a rock reveals the shape-preferred orientation (SPO, shape fabric) or the lattice-preferred orientation (LPO, lattice fabric) of the magnetic minerals, usually iron-bearing oxides, silicates or sulfides (Bouchez, 2000). In igneous rocks containing magnetite (or Ti-poor titanomagnetite), the magnetic fabric is usually dominated by the shape fabric of the individual ferromagnetic grains, as demonstrated by image analyses of ferromagnetic granitoids (Archanjo et al., 1995; Grégoire et al., 1998; Launeau and Cruden, 1998). Distribution anisotropy, due to magnetic interactions between neighboring ferromagnetic grains, has also been advocated to be a potentially important source of AMS in magnetitebearing igneous rocks (Hargraves et al., 1991; Grégoire et al., 1995; Cañón-Tapia, 1996). According to Hargraves et al. (1991), distribution anisotropy would be particularly significant in basaltic rocks, where the magnetite grains are irregular in shape, often skeletal. Actually, AMS would be dominated by the distribution anisotropy of magnetite grains only when these grains are "small, equant and arranged into clusters" (Gaillot et al., 2006).

Both the thermomagnetic experiments and the $K_{m}$ values indicate that a Ti-poor (ferromagnetic) titanomagnetite is the main contributor to magnetic susceptibility in the Egersund dikes, paramagnetic minerals (augite, olivine, ilmenite) playing an additional, minor role in the few low-susceptibility rocks. The AMS signal is therefore dominated by the shape fabric of the titanomagnetite grains likely associated with a contribution of distribution anisotropy impossible to quantify. Rare titanomagnetites probably correspond to early-crystallized, inherited crystals, as suggested by the occurrence of oxide micro-phenocrysts present in the chilled margins. However, the common interstitial character of titanomagnetite indicates that this oxide is mostly a late-crystallization phase, a usual situation in mafic volcanic rocks. Moreover, since the silicate framework probably controls the late growth of titanomagnetite, the latter is expected to mimic the silicate shape fabric, itself dominated by the plagioclase subfabric (Hargraves et al., 1991; Callot and Geoffroy, 2004; Aubourg et al., 2008).

An investigation of the relationship between the magnetic fabric, dominated by titanomagnetite, and the plagioclase shape fabric was conducted through an image analysis study. For this purpose, three mutually orthogonal thin sections were cut in ten AMS samples from five selected sections of the dike swarm, representative of the different types of magnetic fabric observed in the Egersund dikes (DO3-3, one sample; DO1-1, DO5-2 and D07-1, two samples for each section; DO6-1, three samples). A 2D analysis of the SPO of the plagioclase laths visible on these sections was made using the intercept method (Launeau and Robin, 2005; Launeau et al., 2010). An ellipsoid representative of the plagioclase shape fabric of each sample was reconstructed and compared with the AMS ellipsoid (Table 2; Fig. 12).

\subsection{Consistent fabrics}

For seven out of ten samples (DO3-3T; DO5-2E, H; DO6-1A, U; DO7-1K, Q), the magnetic fabric orientation is consistent with the orientation of the plagioclase shape fabric. The angular deviation between the principal axes is rather low $\left(\leq 23^{\circ}\right)$, except for DO6-1U for which an angular deviation of $29^{\circ}$ for the long axes, and $40-43^{\circ}$ for the short and intermediate axes is observed. Such a large discrepancy is acceptable, since DO6-1U is characterized by an oblate magnetic fabric, with $K_{3}$ much better defined than $K_{1}$ and $K_{2}$, whereas the plagioclase shape fabric is prolate, with a long axis much better defined than the short and intermediate axes (Table 2; Fig. 12). The AMS signal in these specimens reflects the silicate fabric, hence represents a primary fabric. These results demonstrate that: (1) the asymmetrical pattern displayed by the magnetic fabric in many sections is consistent with the primary petrofabric; and (2) gently-plunging lineations are dominant, except locally.

\subsection{Fabrics related to mineral alteration}

The moderate to strong discrepancy observed between the AMS axes and the plagioclase shape fabric axes for sample D01-1C (deviation $\geq 45^{\circ}$; Table 2; Fig. 12 ) points to a magnetic fabric strongly influenced by alteration (this sample is from the southern marginal portion of a $\mathrm{d} 1 \mathrm{sub}-$ dike, characterized by a strong 
(a)
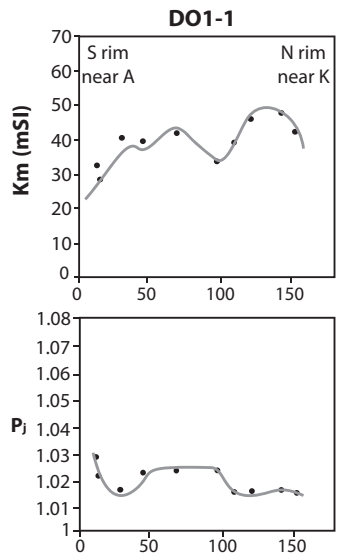

$\mathbf{T}_{\mathbf{j}}$

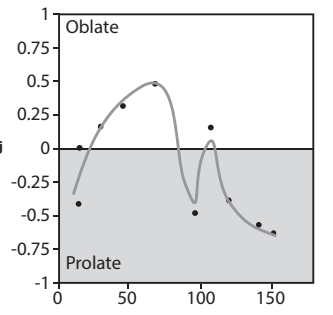

(b)
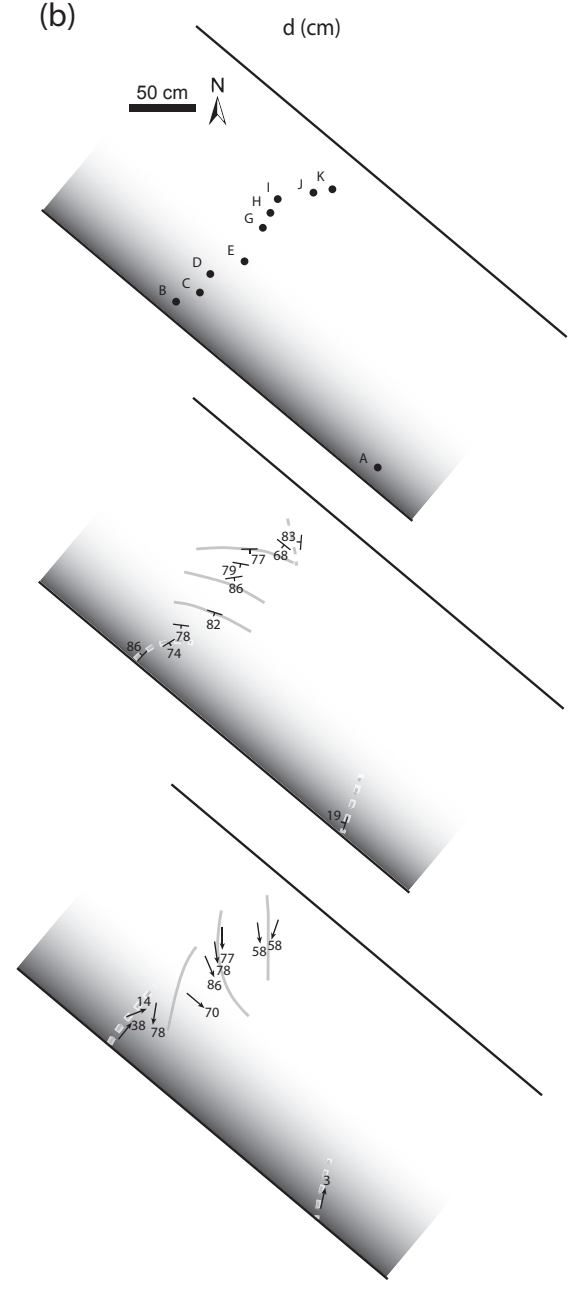

D01-2
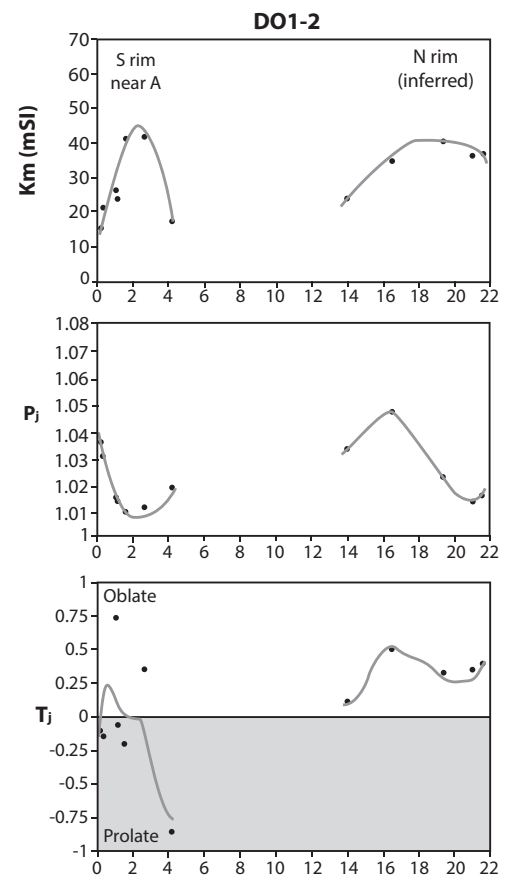

$\mathrm{d}(\mathrm{m})$
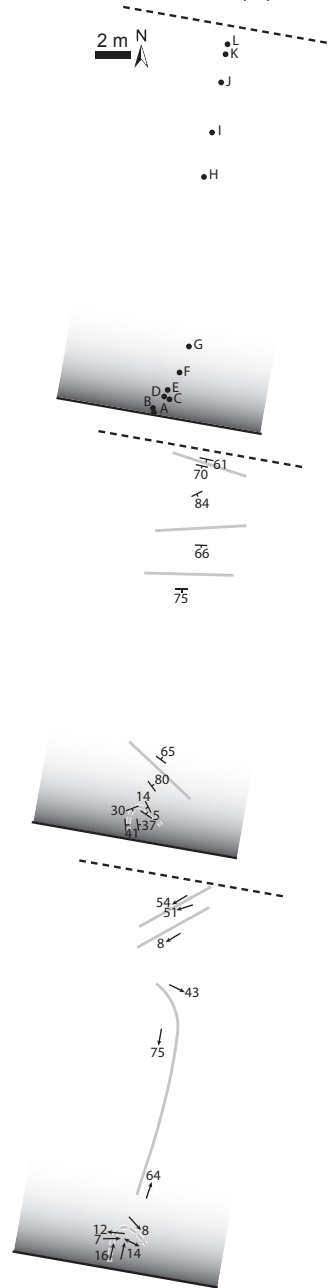
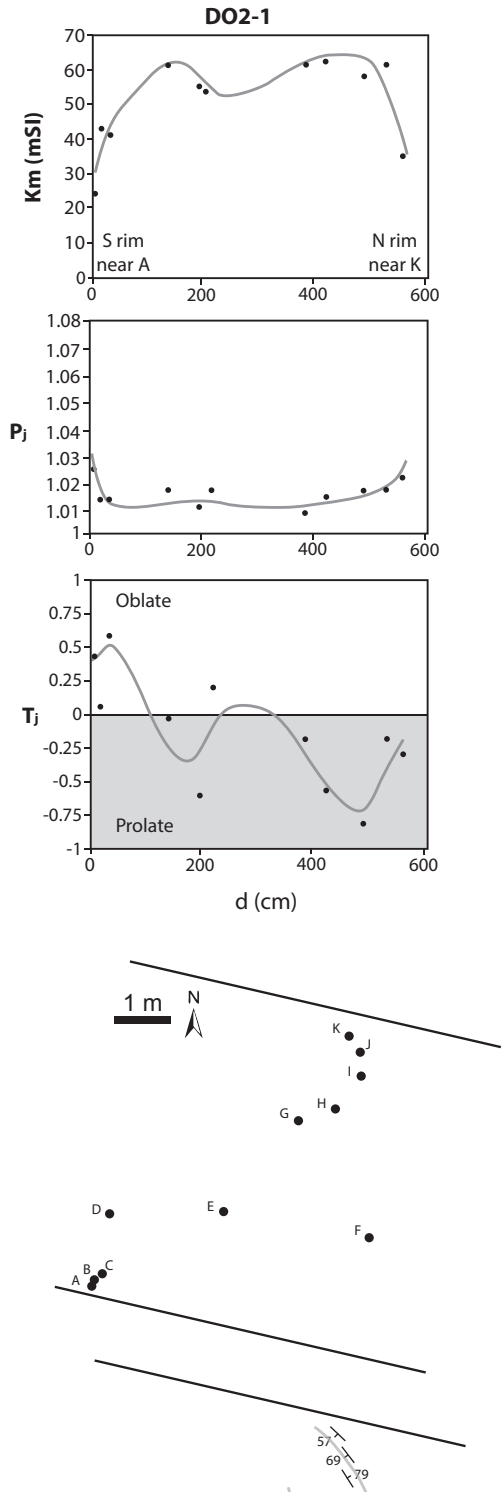

$64 t{ }_{66} \nmid$
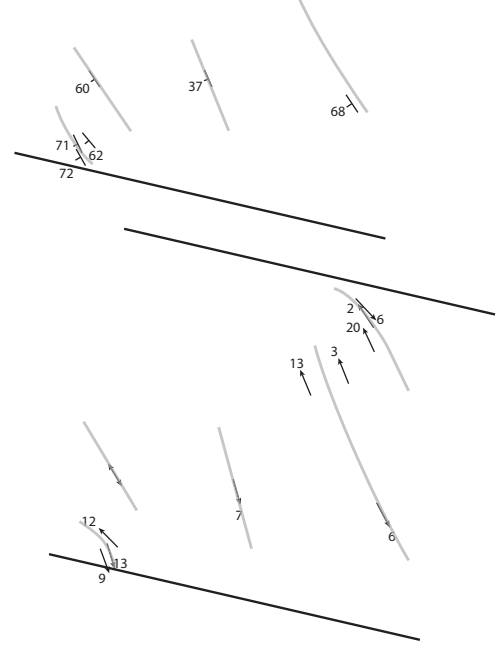

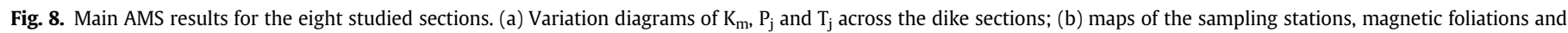

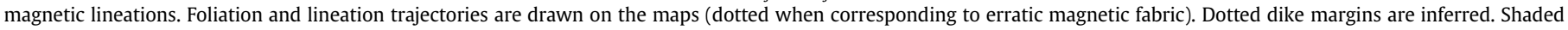
areas at the southern margins of D01-1 and D01-2, and in the center of D06-1 are strongly altered zones. 


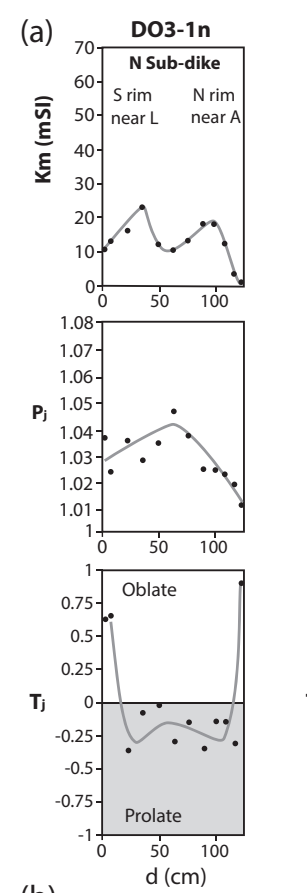

(b)
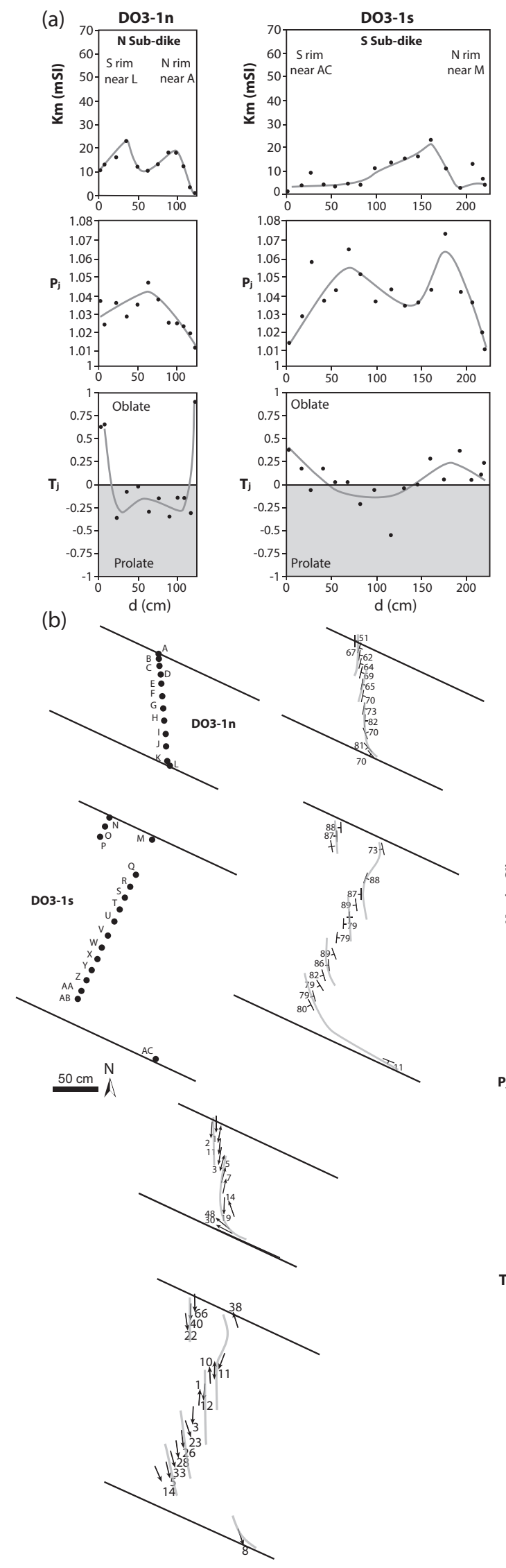

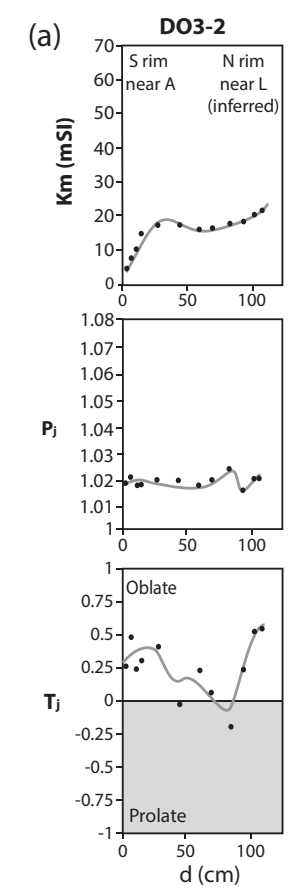

(b)

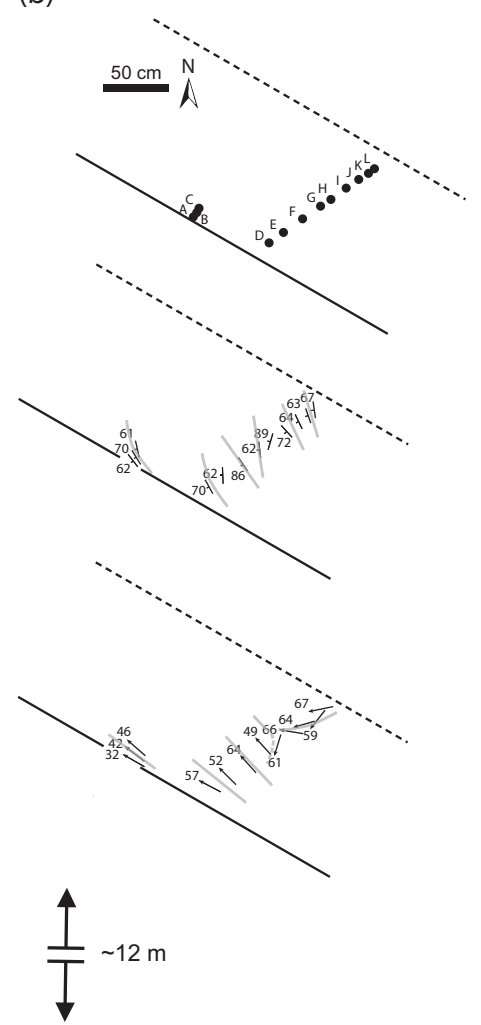

(a)

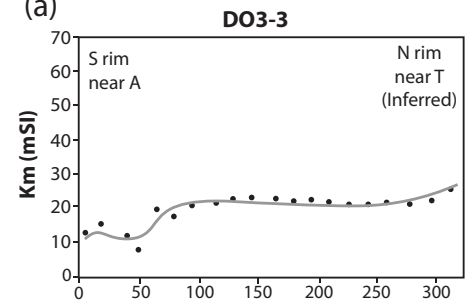

(b)

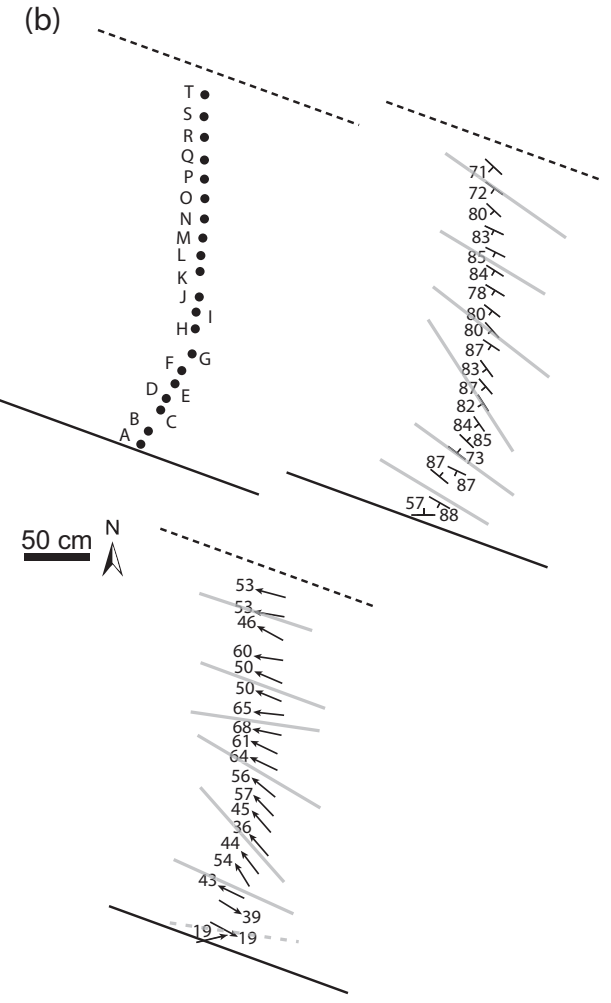

Fig. 8. (continued) 

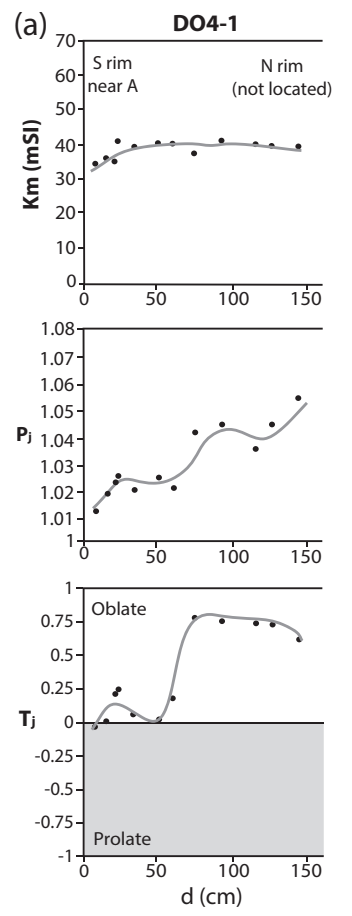

(b)

$50 \mathrm{~cm} \stackrel{N}{\wedge}$
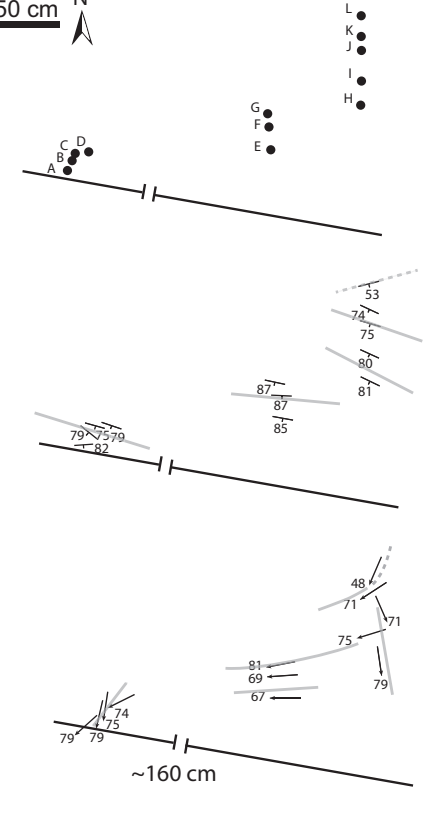

(b)

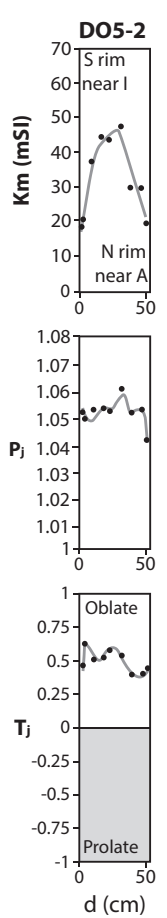

(a)
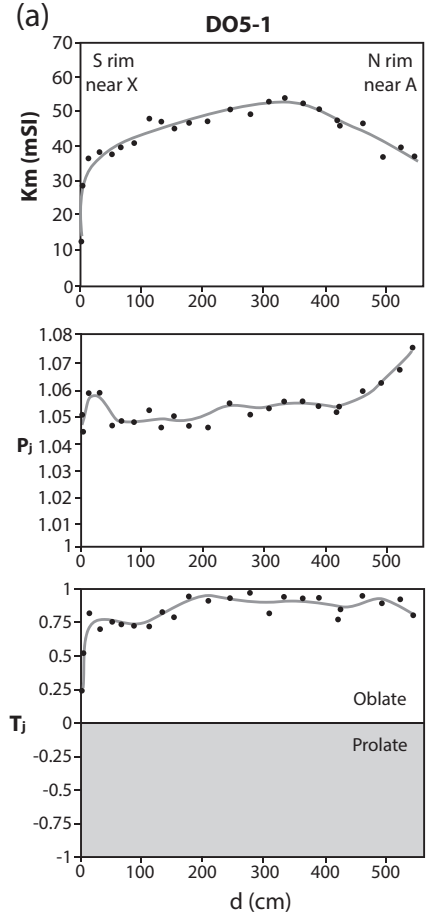

(a) ${ }_{70}^{\text {DO4-2 }}$

(b)
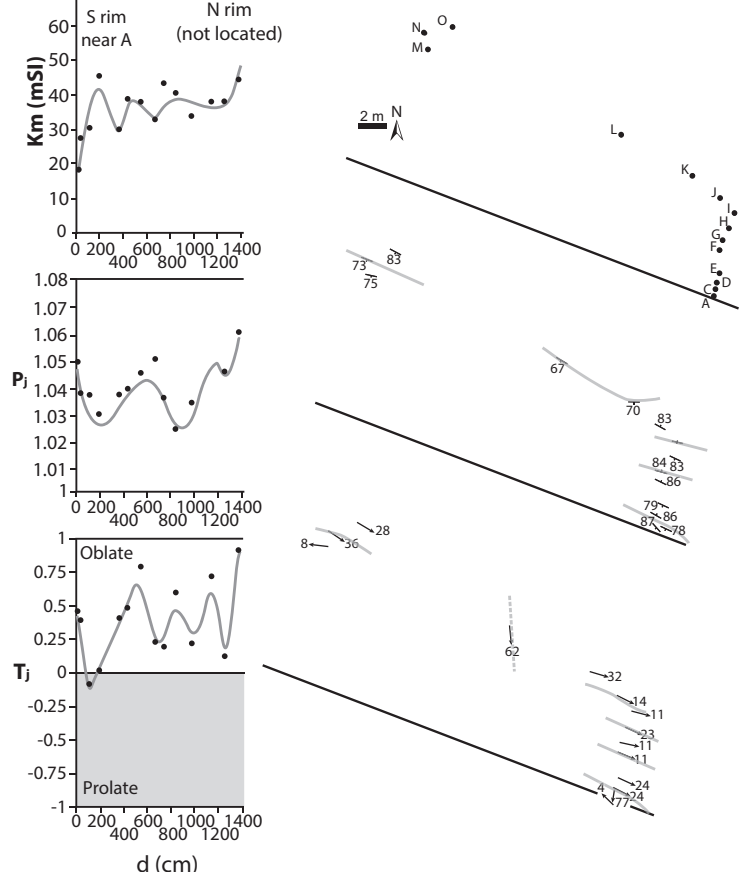

$8-36$

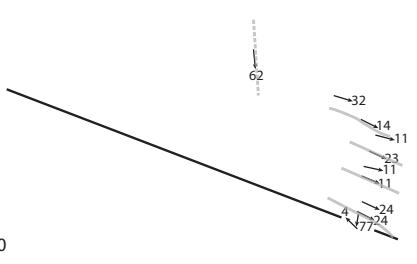

D05-1
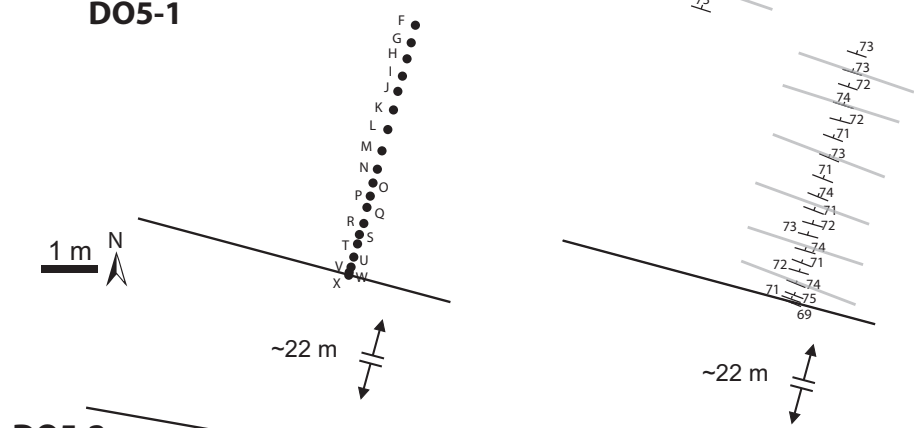

D05-2

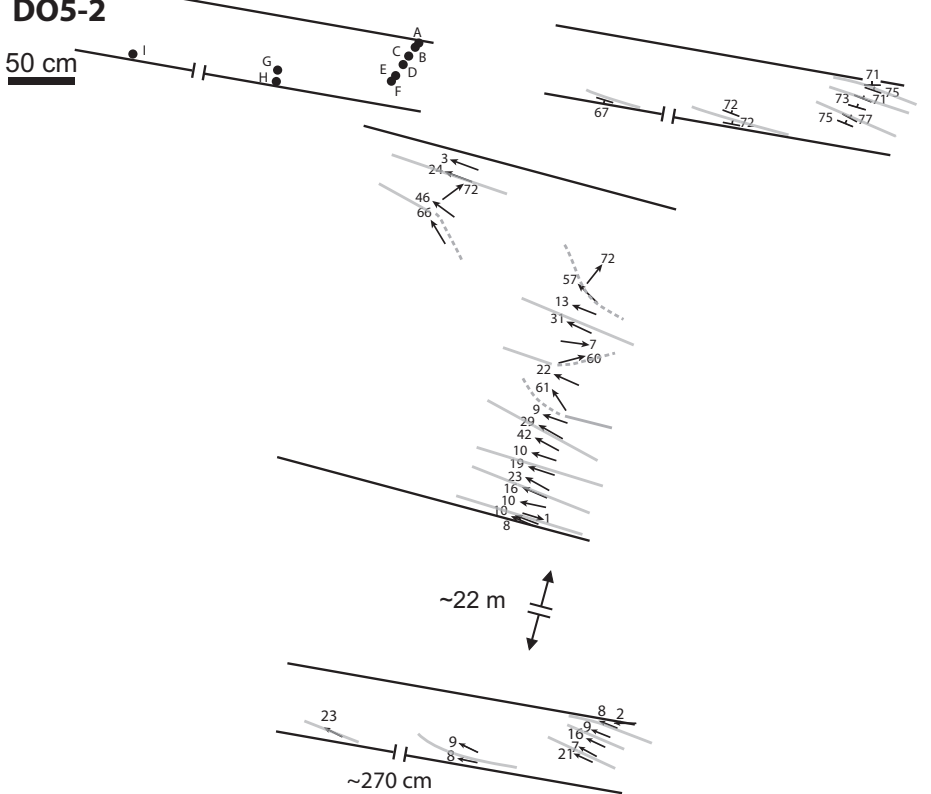

Fig. 8. (continued) 


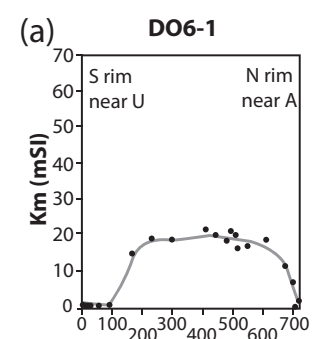

(b)
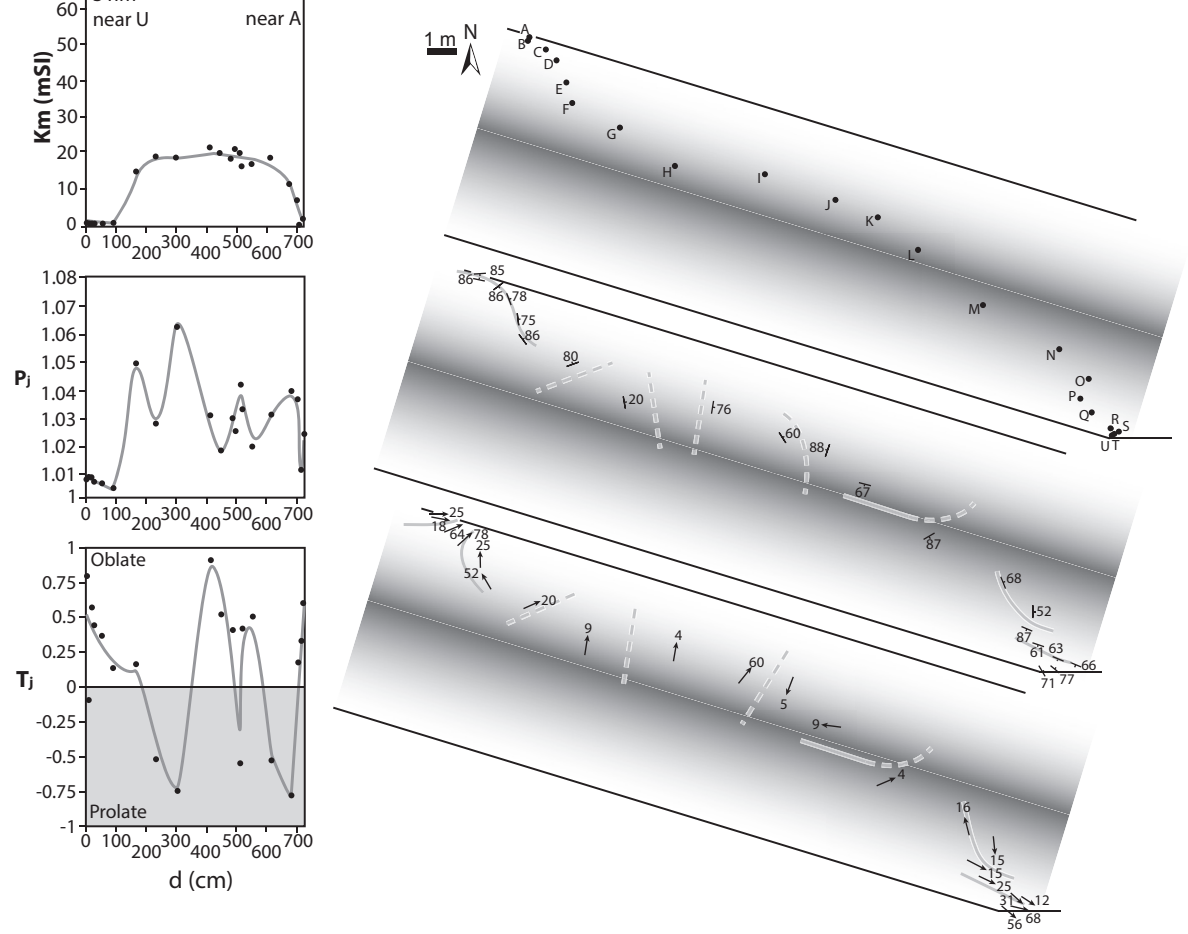

(a)
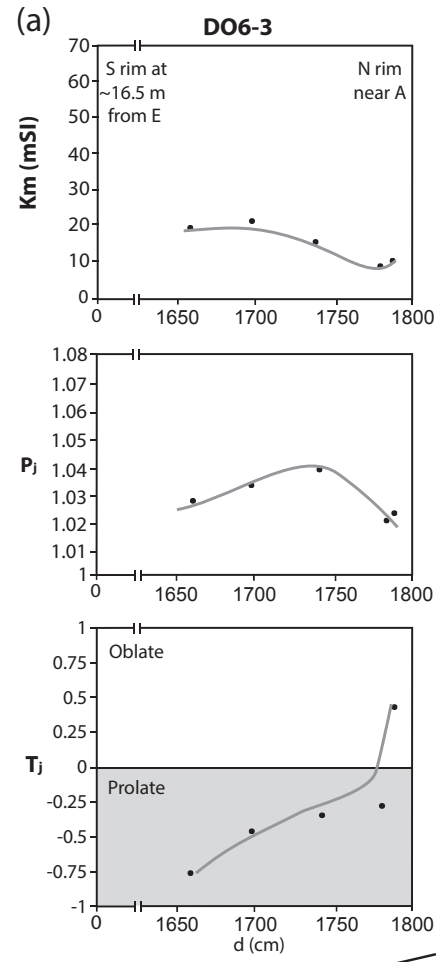

(b)
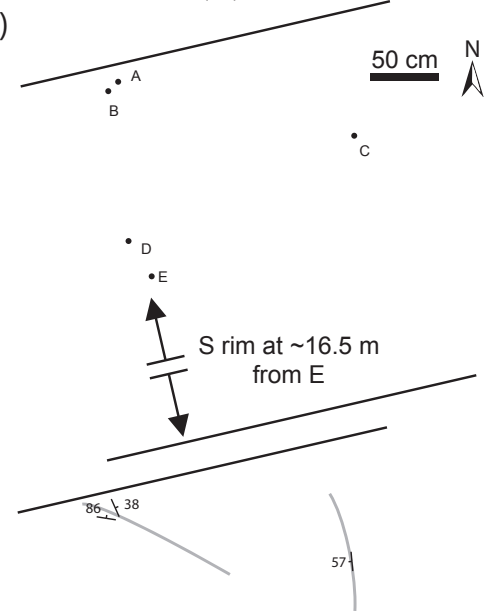

(b)

(a)
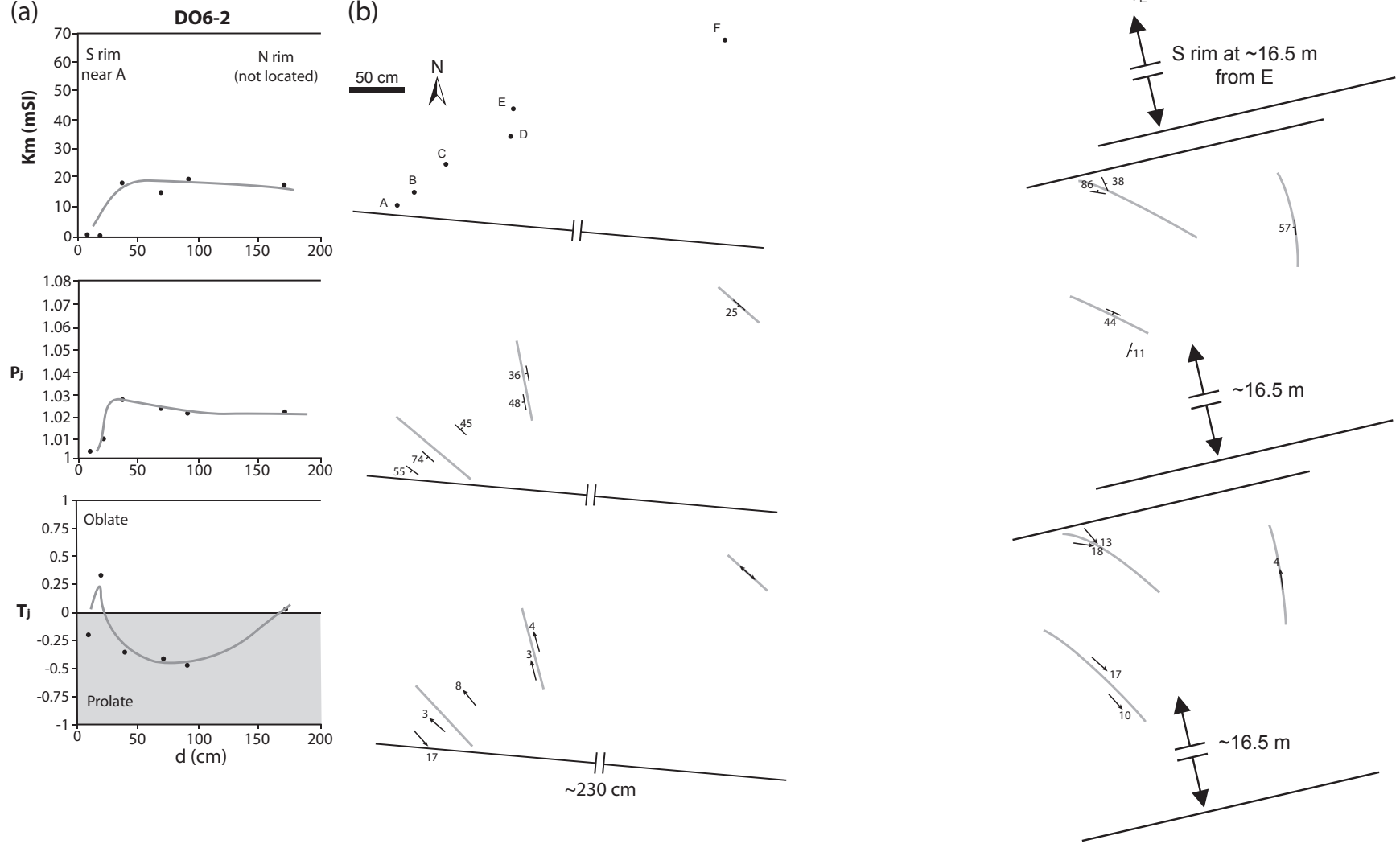

Fig. 8. (continued) 
(a)
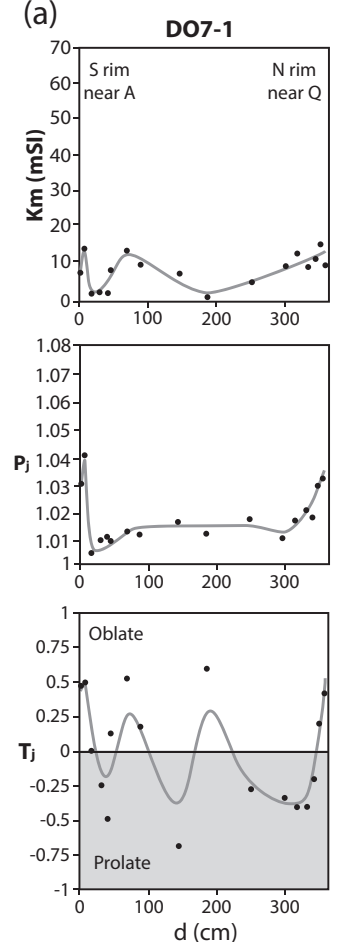

(b)

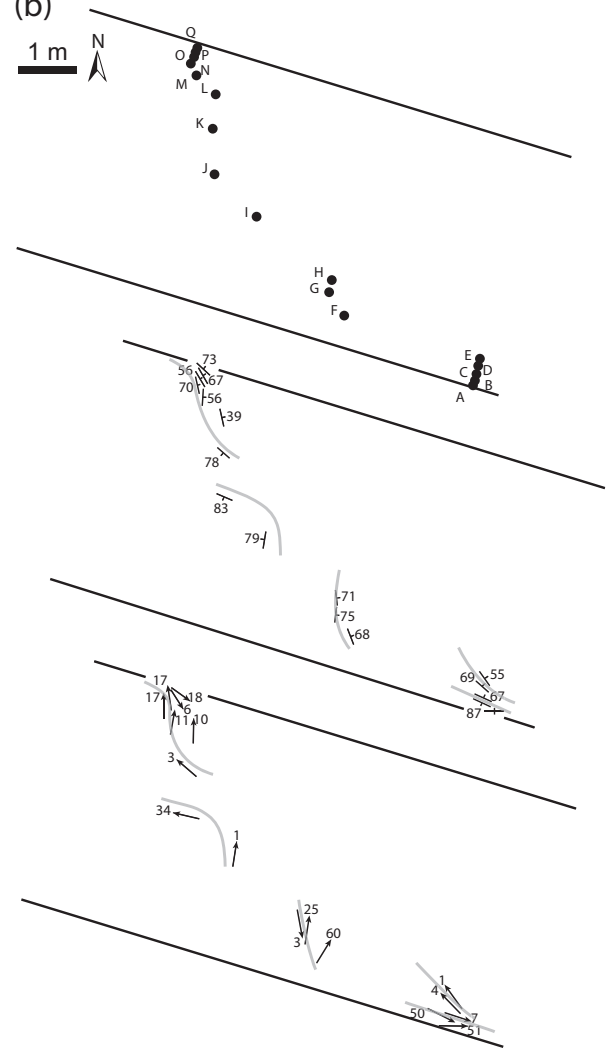

(a)
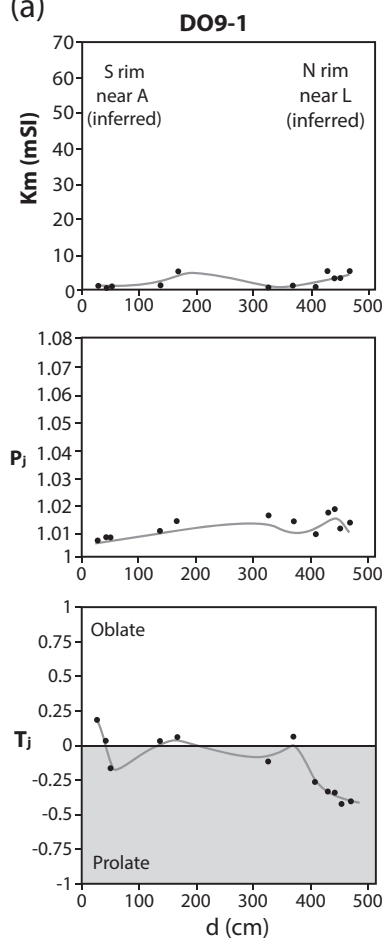

(b)
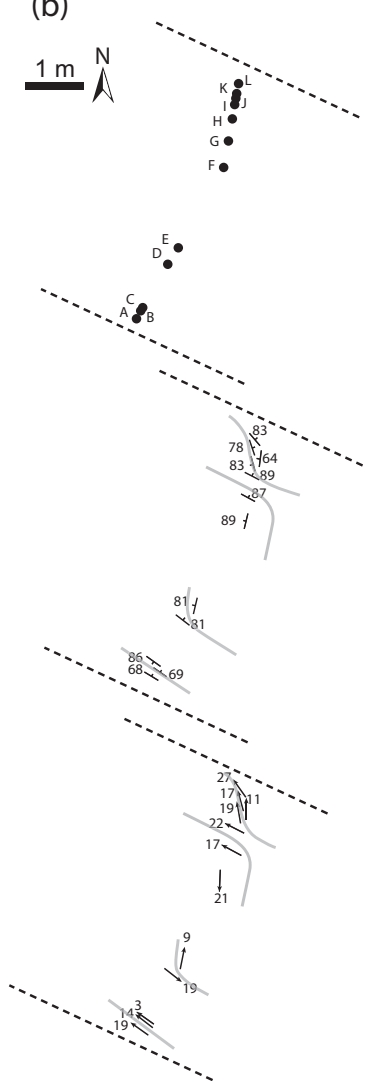

Fig. 8. (continued)

weathering and erratic magnetic fabrics; Fig. 8b). For sample DO1$1 \mathrm{~J}$, representative of the rest of the $\mathrm{d} 1 \mathrm{sub}$-dike, which is less altered and has a more homogeneous magnetic fabric (Fig. 8b), the short axes are roughly concordant (deviation of $32^{\circ}$ ) but the intermediate and long axes are at high angles $\left(\sim 80^{\circ}\right.$; Table 2 ; Fig. 12$)$. Contrary to what suggests the homogenous pattern of the magnetic fabric in the surroundings of DO1-1J, the magnetic fabric of this sample is also influenced by alteration that possibly led to an inversion of $K_{1}$ and $K_{2}$ also favored by a prolate ellipsoid of the magnetic fabric $\left(T_{j} \sim-0.6\right)$. The orientation of the plagioclase shape fabric is similar for samples DO1-1C and DO1-1J, with a steeply-dipping foliation striking at a low angle $\left(15^{\circ}-20^{\circ}\right)$ to the dike plane and a gentlyplunging lineation parallel to the foliation strike (Table 2; Fig. 12). Such an orientation fits the magnetic fabric pattern observed in many sections and is most probably representative of the primary fabric: the hydrothermal alteration did not modify the shape anisotropy of the plagioclase laths in the studied samples.

Sample DO6-1H was drilled in the central portion of section D06-1 (dike d6), where erratic magnetic fabrics are also associated with a strong alteration (Fig. 8b). As for D01-1C, the marked obliquity between the magnetic and plagioclase fabrics (deviation $>45^{\circ}$; Table 2; Fig. 12) demonstrates the strong influence of weathering on the AMS. The plagioclase fabric of sample D06- $1 \mathrm{H}$ is characterized by a steeply-dipping foliation, parallel to the dike plane and a gently-plunging lineation at low angle to the foliation strike (Table 2; Fig. 12). The orientation of this shape fabric is similar to that of the magnetic fabric of DO6-1L sampled to the east of DO6-1H, also in the altered dike core (Fig. 8b). This points to a less influence of weathering on the magnetic fabric of DO6-1L. Combination of the plagioclase fabric of DO6-1H with the magnetic fabric of DO6-1L and that of the less-altered, marginal portions of the section (Fig. 8b) suggests a nested sigmoidal distribution of the petrofabric, similar to the case described in sections D07-1 and D09-1 (Figs. 8b, 10a and 11a) through the arrangement of the AMS axes.

Given the secondary, or at least composite nature of the AMS for D01-1 and the central part of D06-1, no weight will be given on these sections in the interpretation below. Note that the AMS results from section DO1-2 (the other section sampled from dike d1) are very similar to those from section DO1-1, i.e. erratic fabrics due to a strong alteration close to dike rims and, in the less-altered core, a fabric characterized by steep magnetic foliations and moderate to steep plunges of the magnetic lineations (Fig. 8b). As a consequence, the AMS results from DO1-2 will also be excluded from the discussion, even if the larger thickness of the dike at DO1-2 $(\sim 22.5 \mathrm{~m}$; Table 1$)$ suggests that the hydrothermal alteration had a weaker influence on the AMS.

\section{Asymmetrical fabric: a record of syn-emplacement strike- slip shearing}

When a magma flowing in a dike is strained only by the internal, magma buoyancy-related stress, the resulting arrangement of strain markers, including AMS axes, will by symmetrical with respect to the dike plane (e.g. Blanchard et al., 1979; Féménias et al., 2004). On the contrary, an asymmetrical fabric is usually assumed to reflect syn-emplacement simple shear parallel to dike walls, induced by an external, tectonic-related, not purely-tensile stress (Rochette et al., 1991; Correa-Gomes et al., 2001; Aubourg et al., 2002; Féménias et al., 2004; Creixell et al., 2006; Lefort et al., 2006; Clemente et al., 2007). The asymmetrical trajectories displayed by the foliations and lineations in the studied AMS sections (Figs. 10a 

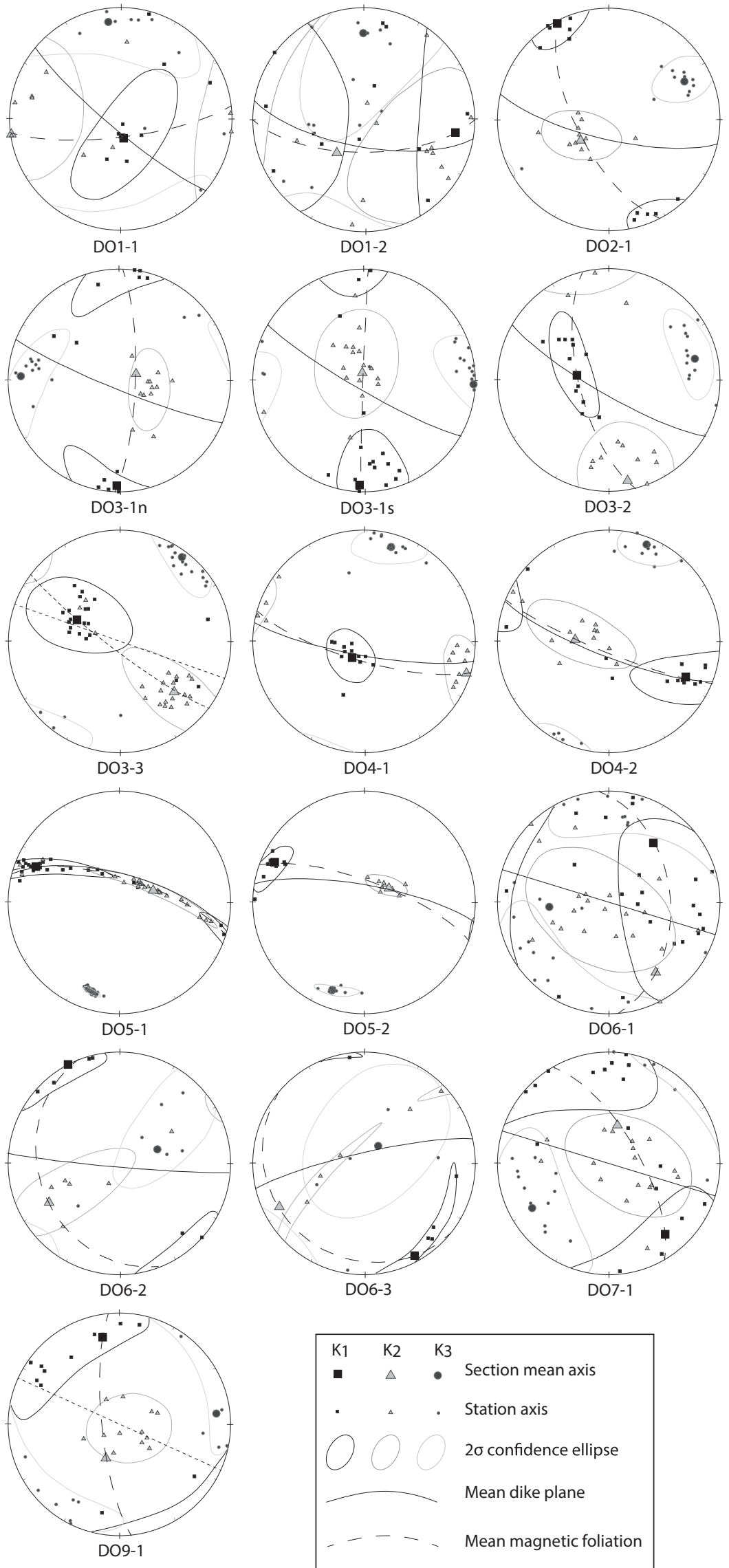

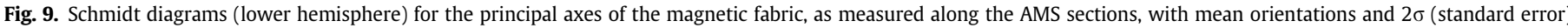
confidence ellipses. The average orientation of the dike plane is also shown for each section (dotted when only the dike strike is known). 
(a)

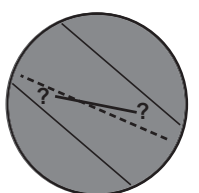

DO1-1

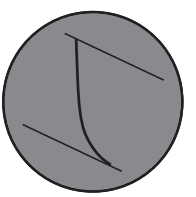

DO3-1s

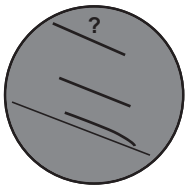

DO4-2

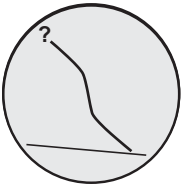

D06-2

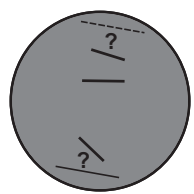

DO1-2

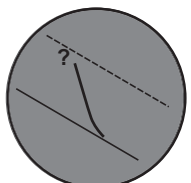

DO3-2

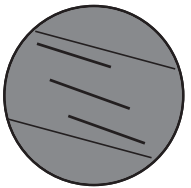

D05-1

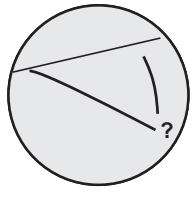

DO6-3

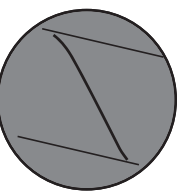

DO2-1

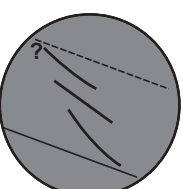

DO3-3

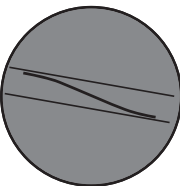

DO5-2

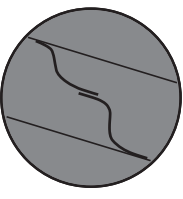

D07-1

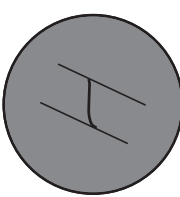

DO3-1n

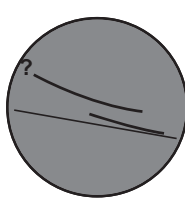

DO4-1

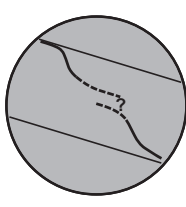

D06-1

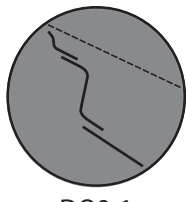

DO9-1

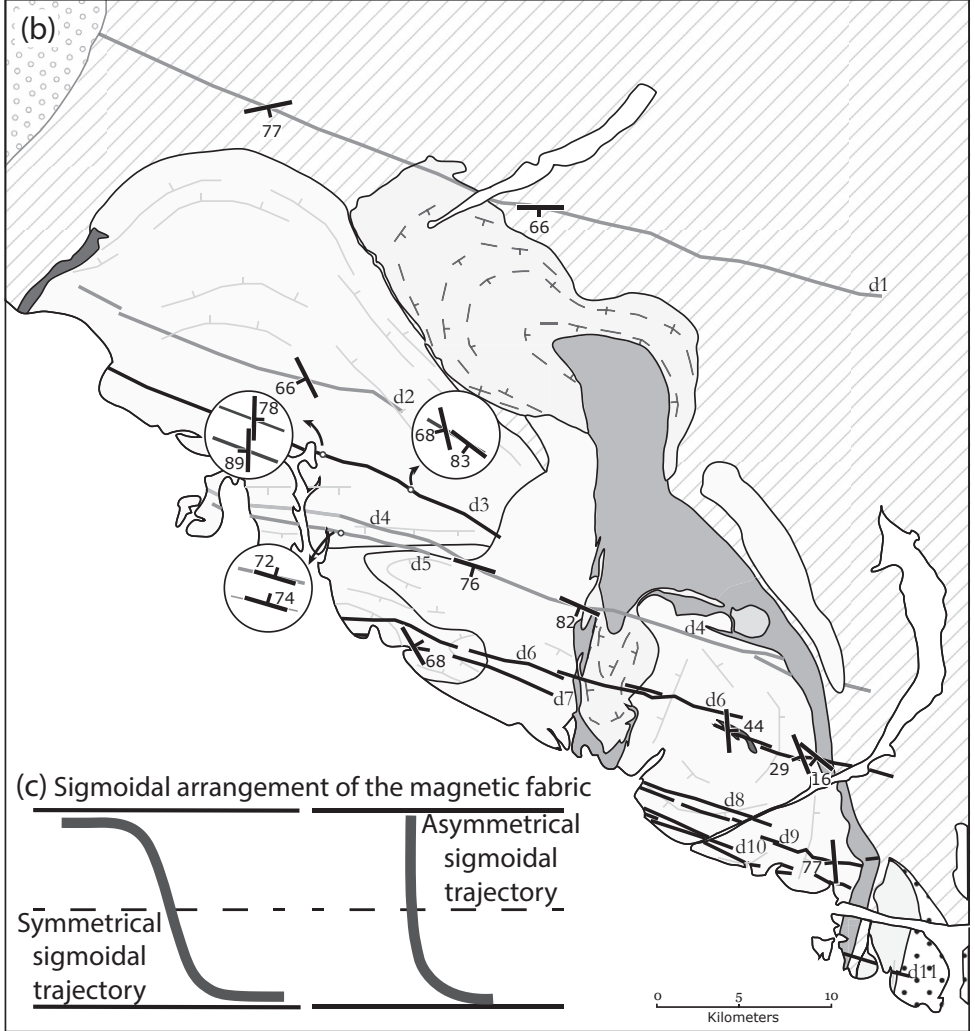

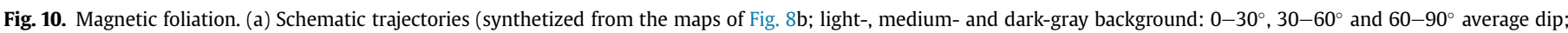

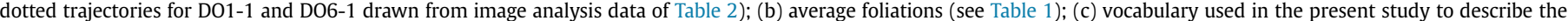
asymmetry of dike fabrics, as seen in map view (it applies to foliations as well as lineations; see Fig. 11a).

(a)

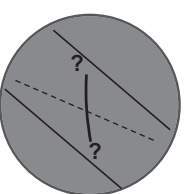

DO1-1

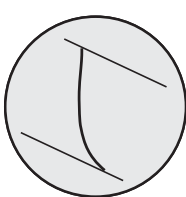

DO3-1s

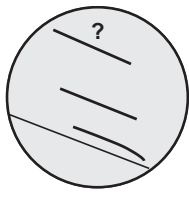

DO4-2

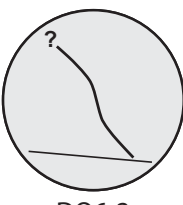

D06-2

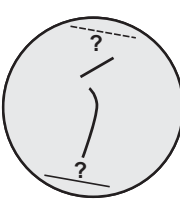

D01-2

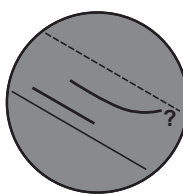

DO3-2

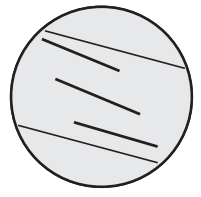

DO5-1

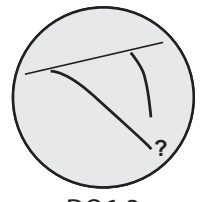

DO6-3

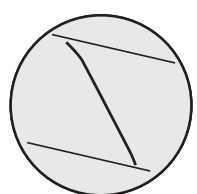

DO2-1

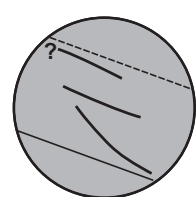

DO3-3

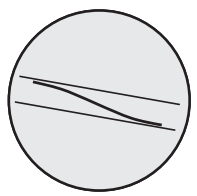

D05-2

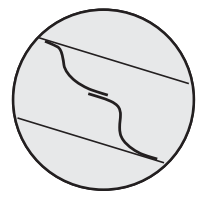

DO7-1

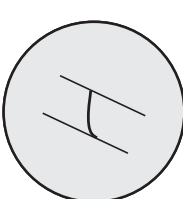

DO3-1n

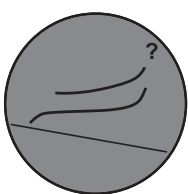

DO4-1

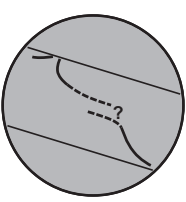

D06-1

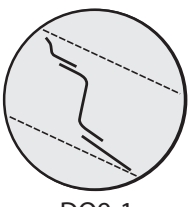

D09-1

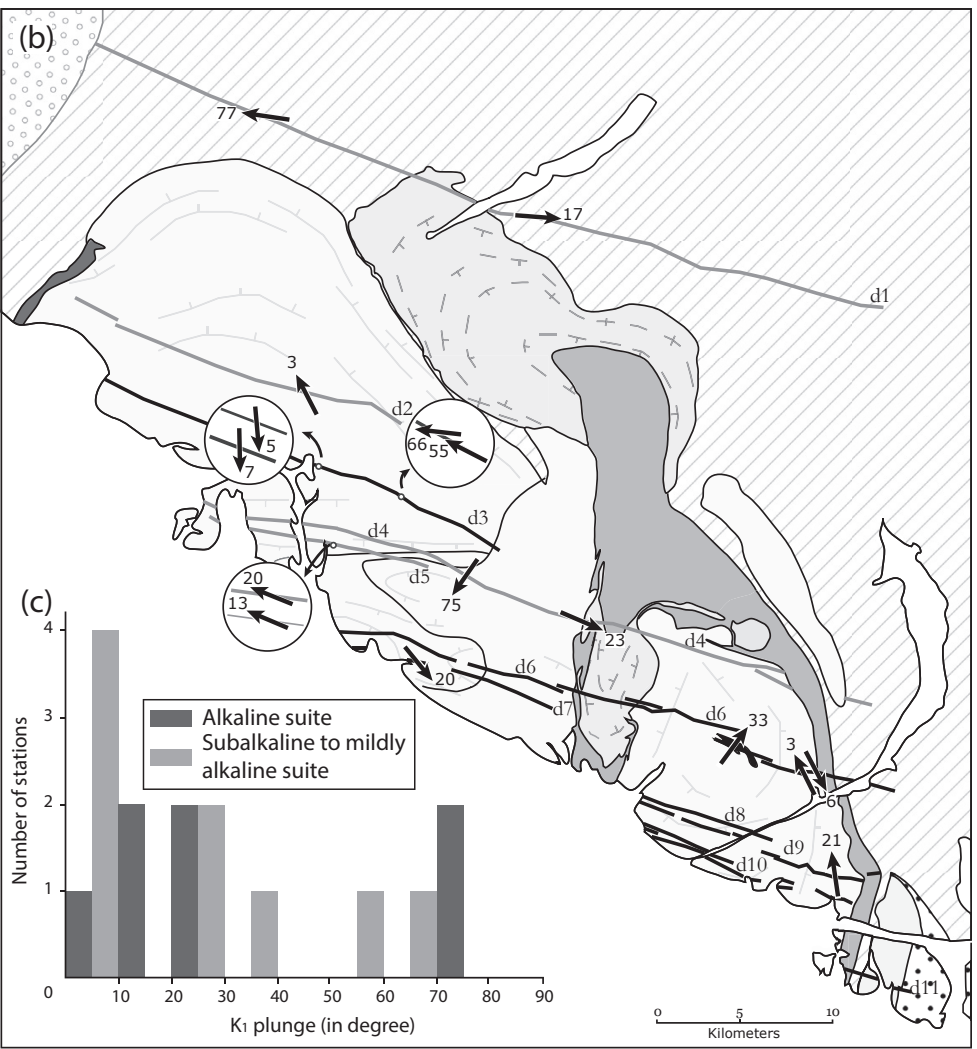

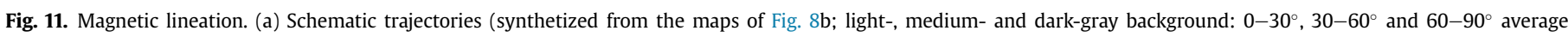

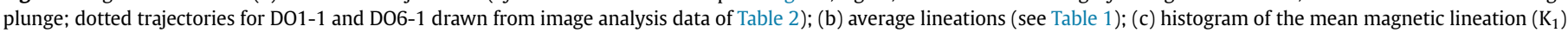
plunges. 
Table 2

Comparison between image analysis and AMS data.

\begin{tabular}{|c|c|c|c|c|c|c|c|c|c|c|}
\hline \multirow[t]{2}{*}{ AMS section } & \multirow[t]{2}{*}{ Sample } & & \multicolumn{2}{|c|}{ A } & \multicolumn{2}{|c|}{ B } & \multicolumn{2}{|c|}{ C } & \multirow[t]{2}{*}{$P_{j}$} & \multirow[t]{2}{*}{$\mathrm{T}_{\mathrm{j}}$} \\
\hline & & & Dec & Inc & Dec & Inc & Dec & Inc & & \\
\hline \multirow[t]{6}{*}{ D01-1 } & C & IA & 297 & 1 & 29 & 67 & 206 & 23 & 2.098 & 0.578 \\
\hline & & AMS & 68 & 14 & 197 & 68 & 334 & 16 & 1.017 & 0.169 \\
\hline & & $\Delta$ & \multicolumn{2}{|c|}{51} & \multicolumn{2}{|c|}{45} & \multicolumn{2}{|c|}{64} & 1.081 & 0.409 \\
\hline & $\mathrm{J}$ & IA & 291 & 30 & 106 & 60 & 200 & 2 & 1.07 & 0.235 \\
\hline & & AMS & 173 & 58 & 302 & 22 & 41 & 22 & 1.016 & -0.593 \\
\hline & & $\Delta$ & \multicolumn{2}{|c|}{78} & \multicolumn{2}{|c|}{83} & \multicolumn{2}{|c|}{32} & 0.054 & 0.828 \\
\hline \multirow[t]{3}{*}{ DO3-3 } & $\mathrm{T}$ & IA & 271 & 54 & 121 & 32 & 22 & 14 & 1.099 & -0.312 \\
\hline & & AMS & 285 & 53 & 144 & 30 & 42 & 19 & 1.031 & 0.074 \\
\hline & & $\Delta$ & \multicolumn{2}{|c|}{8} & \multicolumn{2}{|c|}{20} & \multicolumn{2}{|c|}{20} & 0.068 & 0.386 \\
\hline \multirow[t]{6}{*}{ DO5-2 } & E & IA & 284 & 21 & 88 & 68 & 192 & 6 & 1.194 & 0.286 \\
\hline & & AMS & 299 & 7 & 57 & 75 & 208 & 13 & 1.066 & 0.597 \\
\hline & & $\Delta$ & \multicolumn{2}{|c|}{20} & \multicolumn{2}{|c|}{12} & \multicolumn{2}{|c|}{17} & 0.128 & 0.311 \\
\hline & $\mathrm{H}$ & IA & 280 & 14 & 53 & 70 & 186 & 14 & 1.339 & 0.401 \\
\hline & & AMS & 284 & 8 & 36 & 71 & 191 & 18 & 1.064 & 0.474 \\
\hline & & $\Delta$ & \multicolumn{2}{|c|}{7} & \multicolumn{2}{|c|}{6} & \multicolumn{2}{|c|}{6} & 0.275 & 0.073 \\
\hline \multirow[t]{9}{*}{ D06-1 } & A & IA & 93 & 46 & 256 & 43 & 354 & 8 & 1.179 & 0.583 \\
\hline & & AMS & 92 & 25 & 258 & 64 & 359 & 5 & 1.023 & 0.62 \\
\hline & & $\Delta$ & \multicolumn{2}{|c|}{21} & \multicolumn{2}{|c|}{21} & 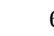 & & 0.156 & 0.037 \\
\hline & $\mathrm{H}$ & IA & 296 & 25 & 81 & 60 & 199 & 15 & 1.162 & 0.123 \\
\hline & & AMS & 14 & 9 & 107 & 17 & 258 & 70 & 1.017 & 0.504 \\
\hline & & $\Delta$ & 7 & & 4 & & 6 & & 0.145 & 0.381 \\
\hline & $\mathrm{U}$ & IA & 145 & 35 & 288 & 48 & 41 & 19 & 1.278 & -0.667 \\
\hline & & AMS & 115 & 56 & 336 & 27 & 236 & 19 & 1.007 & 0.796 \\
\hline & & $\Delta$ & 2 & & 4 & & 4 & & 0.271 & 1.463 \\
\hline DO7-1 & K & IA & 333 & 8 & 186 & 80 & 64 & 5 & 1.071 & -0.787 \\
\hline & & AMS & 311 & 3 & 208 & 78 & 42 & 12 & 1.019 & -0.292 \\
\hline & & $\Delta$ & 2 & & 5 & & 2 & & 0.052 & 0.495 \\
\hline & $\mathrm{Q}$ & IA & 129 & 12 & 332 & 77 & 220 & 5 & 1.081 & 0.607 \\
\hline & & AMS & 127 & 18 & 353 & 64 & 223 & 17 & 1.039 & 0.424 \\
\hline & & $\Delta$ & 7 & & 1 & & 1 & & 0.042 & 0.183 \\
\hline
\end{tabular}

A, B, C: declination (Dec) and inclination (Inc) of the long (A), intermediate (B) and short (C) principal axes ( $A, B, C$ correspond to, respectively, $K_{1}, K_{2}, K_{3}$ for the magnetic fabric); $\mathrm{P}_{\mathrm{j}}$ : anisotropy degree of Jelínek (1981); $\mathrm{T}_{\mathrm{j}}$ : shape parameter of Jelínek (1981); IA: data for the plagioclase shape fabric defined through image analysis; AMS: data for the magnetic fabric; $\Delta$ : difference (absolute value) between IA and AMS data.

and 11a) indicate that the present dike swarm was emplaced in a tectonic strain field inducing shearing along the dike walls. Such a scenario implies that simple shear resolved on dike walls was induced by magma flow combined with tectonic shearing. Such a composite strain is likely responsible for the well-expressed SPO of plagioclase (micro)phenocrysts commonly observed close to dike margins (Fig. 4c) and locally associated with an increase of the $P_{j}$ parameter (Fig. 8a).

Correa-Gomes et al. (2001) and Clemente et al. (2007) have proposed simple models to depict fabric development in dikes under coeval external shearing and internal magma flow shearing. These models predict different kinds of fabric patterns, depending on the respective shearing rates. They can be used to interpret the asymmetric fabric pattern evidenced in the Egersund dike swarm, in order to evaluate the relative importance of magma flow vs. tectonic shearing. Accordingly, the more-or-less symmetrical sigmoidal trajectories usually observed for the most complete sections (Figs. 10a and 11a) would reflect a dominance of tectonic shearing on fabric development, whereas the strongly asymmetrical sigmoidal trajectories (sections DO3-1s and DO3-1n; Figs. 10a and 11a) would indicate a lower influence of tectonic shearing. The strongest effect of tectonic shearing was recorded along sections D04-1, DO4-2, D05-1 and D05-2 that are characterized by weaklyasymmetrical magnetic fabrics (Figs. 10a and 11a) associated with quite anisotropic and oblate AMS ellipsoids (Table 1; Fig. 8a). In conclusion, tectonic and magma flow shearing seem to interact at various degrees across the present dike swarm, with however a domination of tectonic shearing. The nested sigmoidal patterns observed in DO7-1 and DO9-1 (Figs. 10a and 11a) are not attributed to "dike-in-dike" emplacement, i.e. to successive magma injections (Baer, 1995; Lefort et al., 2006) since the $K_{m}, P_{j}$ and $T_{j}$ profiles (Fig. 8a) do not display any marked variation in the nested part of the dikes. These patterns more likely result from within-dike localization of the tectonic shearing.

The usually curved trajectories of the magnetic foliations and lineations have, of course, similar shapes only where lineations are gently plunging, i.e. sub-parallel to foliation strike. In the rare cases where the lineation plunges are moderate to steep, shapes may be different and the curvature may even be opposite (e.g. DO4-1; Figs. 10a and 11a). Having clarified this issue, we observe from the shape of the foliation trajectories and that of the gently plunging lineations (Figs. 10a and 11a) that the syn-emplacement shearing corresponds to a sinistral strike-slip movement.

\section{Constraints on magma flow orientation}

\subsection{Within-dike magma injection}

Many authors consider that the magnetic lineation in volcanic dikes is parallel to the flow direction (Knight and Walker, 1988; Rochette et al., 1991; Ernst and Baragar, 1992; Raposo and Ernesto, 1995; Varga et al., 1998; Raposo and D'Agrella-Filho, 2000; Borradaile and Gauthier, 2006; among others). Moreover, inclination of the magma flow, as deduced from the magnetic lineation orientation, can be used theoretically to infer the emplacement mode and the relative position with respect to the feeding magma chamber(s). This exercise has been put forward in numerous AMS investigations of Mesozoic and Proterozoic mafic dike swarms from Brazil (review in Raposo, 2011).

According to the classic emplacement scenarios of mafic dike swarms in the continental crust (Cadman et al., 1990; Callot et al., 2001; Creixell et al., 2009), steeply-plunging magma flow indicates sub-vertical magma injection from a mantle or subcrustal source, whereas predominantly gently-plunging flow witnesses lateral magma injection, likely from a high-level plutonic complex. The latter case is similar to what is observed in some dikes emplaced beneath subaerial volcanoes in oceanic environments, such as in Hawaii (Knight and Walker, 1988). Inclination of the magma flow in mafic dikes emplaced from a deep-seated magma chamber may however vary along dike swarm. This has been demonstrated by the magnetic fabric analysis of the Mackenzie giant dike swarm of Canada (Ernst and Baragar, 1992) in which the magnetic lineation is vertical near the center of the plume and horizontal away from it. Similarly, the AMS data from the sheeted dikes of the Troodos ophiolite complex (Cyprus) indicate gradual systematic variations in the inclination of the magma flow, from subhorizontal to near-vertical (Staudigel et al., 1992; Varga et al., 1998; Borradaile and Gauthier, 2006), leading to a model of emplacement from spaced magma chambers, with steep flow above the feeding zones and lateral flow away from them. The propagation mode of magma in mafic dike swarms (vertical vs. lateral) would be mainly controlled by buoyancy contrasts with the host rocks (Lister and Kerr, 1991). Evolution from one mode to the other in a single dike swarm would reflect the evolution of the magma rheology through time due to cooling away from the feeding zone, inducing a reduction of the buoyancy contrasts as well as a blocking of the dike tips (Cadman et al., 1992; Féménias et al., 2004).

We propose for the Egersund dike swarm a model in which sub-vertical injection took place from below, with magma cooling during ascent in the crust, likely combined with strikeslip shearing to explain that average magnetic lineations with low plunges are dominating the magnetic fabric (Fig. 11b). Areas of the swarm dominated by moderately-to steeply-plunging 


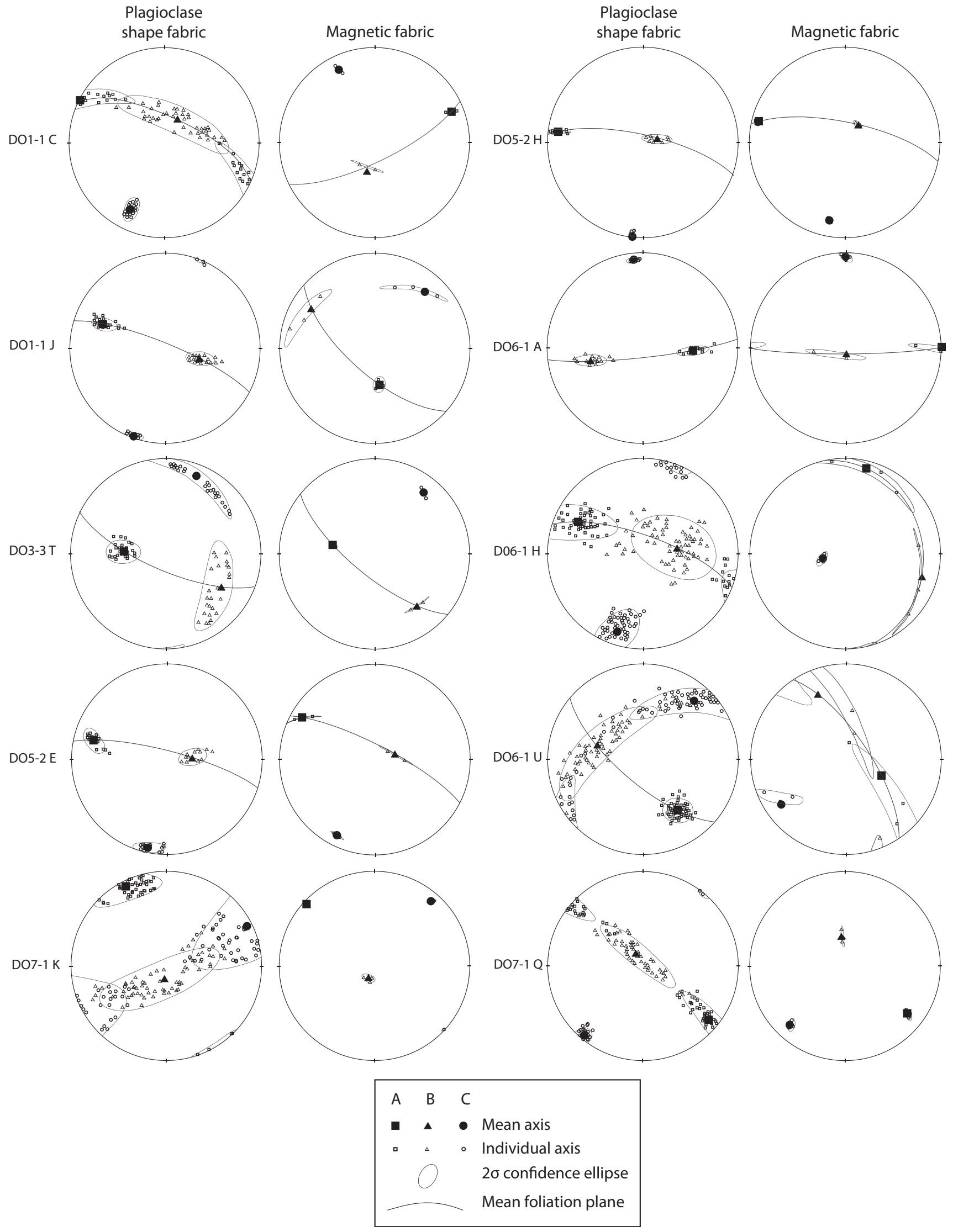

Fig. 12. Principal axes of the plagioclase shape fabric obtained from image analysis for ten samples, represented in a lower hemisphere Schmidt diagram, with $2 \sigma$ confidence ellipses. Equal-area projections of the principal axes of the corresponding magnetic fabric are shown to the right, for sake of comparison. A, B, C: long, intermediate, short principal axis $\left(\mathrm{K}_{1}, \mathrm{~K}_{2}, \mathrm{~K}_{3}\right.$ for the magnetic fabric); mean foliation plane: mean $\mathrm{AB}$ plane $\left(\mathrm{K}_{1} \mathrm{~K}_{2}\right.$ for the magnetic fabric). 


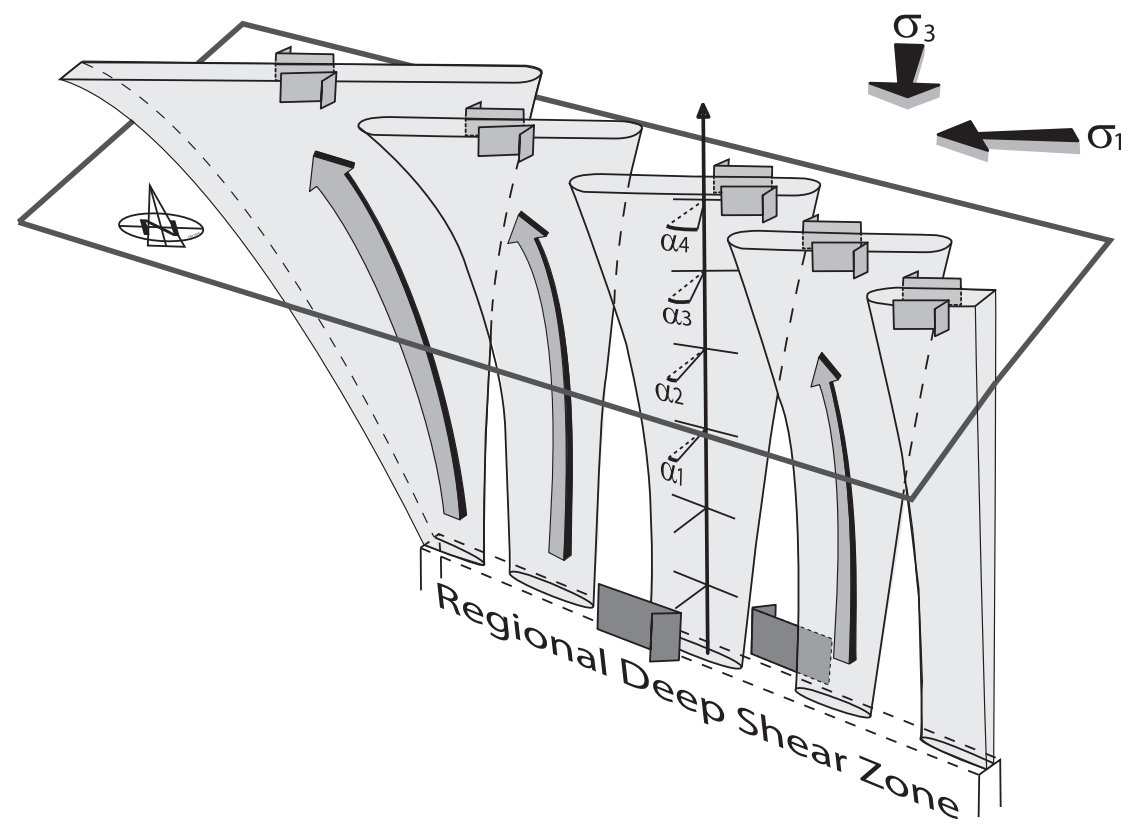

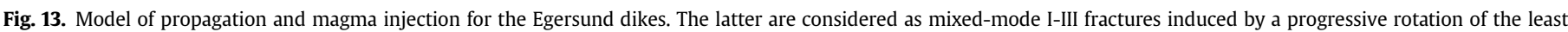
compressive stress about an axis parallel to the propagation direction (adapted from Delaney and Pollard, 1981).

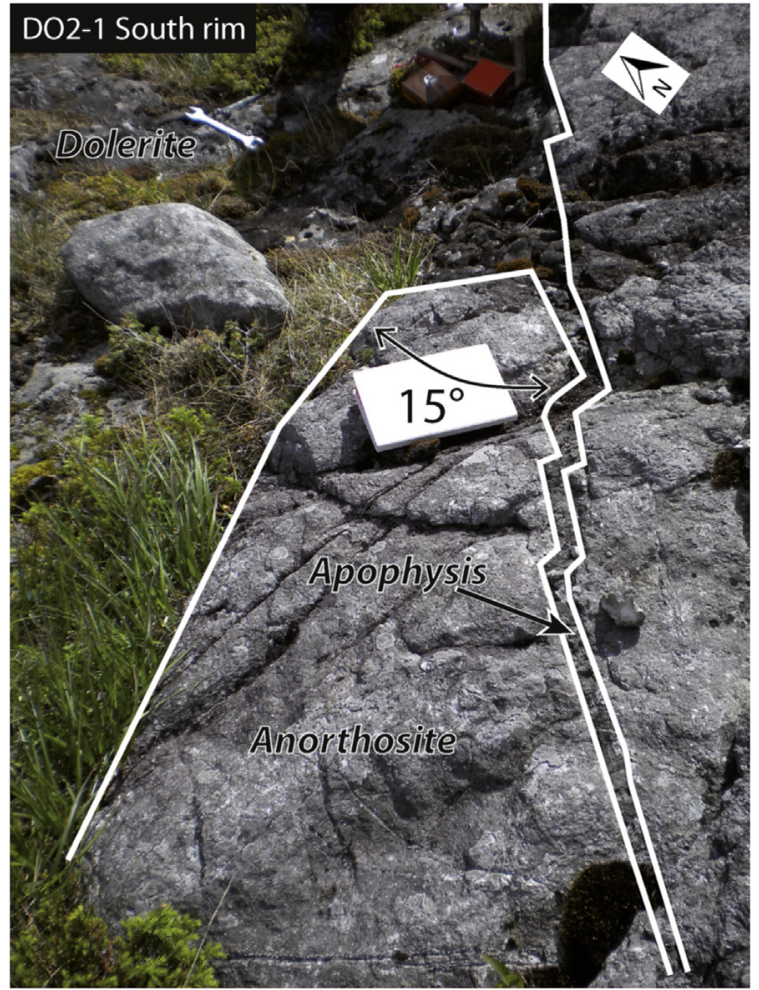

Fig. 14. Field photograph of an en-échelon, lateral branch ("apophysis") at the southern rim of dike d2 (section DO2-1), suggesting a westward-directed horizontal component of magma flow. The length of the notebook is $19.4 \mathrm{~cm}$.

magnetic lineations (sections DO3-2 and DO3-3, ends of sections DO3-1n and DO3-1s, dike d3; section DO4-1, dike d4; Figs. 8b and $11 \mathrm{~b}$ ) would be zones where steeply-inclined flow lines are partly preserved. Our model of within-dike magma injection is presented in Fig. 13. In this model, the Egersund dikes are interpreted as segmented dikes whose propagation is perpendicular to the resolved shear, resulting from magma filling into mixed-mode I-III fractures (Pollard, 1987) above a deep-seated regional sinistral shear zone. It is worth noting that at least two subcrustal feeding magma chambers were located below the swarm, since, according to Bingen and Demaiffe (1999), the dikes were fed by magmas ponded at the Moho that were derived from at least two distinct asthenospheric sources.

\subsection{Imbrication and sense of flow}

It has long been recognized that a slight imbrication of the magnetic lineation, reflecting the tiling of mineral particles (Blanchard et al., 1979), is common along the walls of dikes and can be used to infer the sense of magma flow, the imbrication angle (acute angle between magnetic lineation and dike margin) pointing in the same direction as the magma flow (Knight and Walker, 1988; Staudigel et al., 1992; Baer, 1995; Arbaret et al., 1996; Tauxe et al., 1998; Varga et al., 1998; Callot et al., 2001). In recent studies, the magnetic foliation imbrication, instead of lineation imbrication, has been often used preferentially to determine both the direction and sense of magma flow, because $K_{1}$ is not always a reliable indicator of magma flow (e.g. Geoffroy et al., 2002; among others). In dikes that have been submitted to syn-magmatic tectonic shearing, if the magma flow and shear vectors were close enough from each other, flow is given by the less imbricated fabric (smallest angle), after Correa-Gomes et al. (2001) and Clemente et al. (2007). For this purpose, we have selected the most complete AMS sections showing clearly distinct imbrication angles at both dike rims. In the three appropriate sections, namely DO3-1n, DO3-1s and DO7-1 (Fig. 8b), the smallest imbrication angle is observed at the southern margin, both for lineation and foliation, and its orientation indicates a westward magma flow. This agrees with the westwarddirected horizontal component of magma flow that can be deduced from the orientation of lateral branches or "apophyses" (Rickwood, 1990; Correa-Gomes et al., 2001) making an acute angle with the dike trend, as observed locally on subhorizontal outcrops (Fig. 14). It is thus reasonable to assume a westward component of flow in the model of Fig. 13 (vertical flow gradually passing to a less steep, westward flow). 


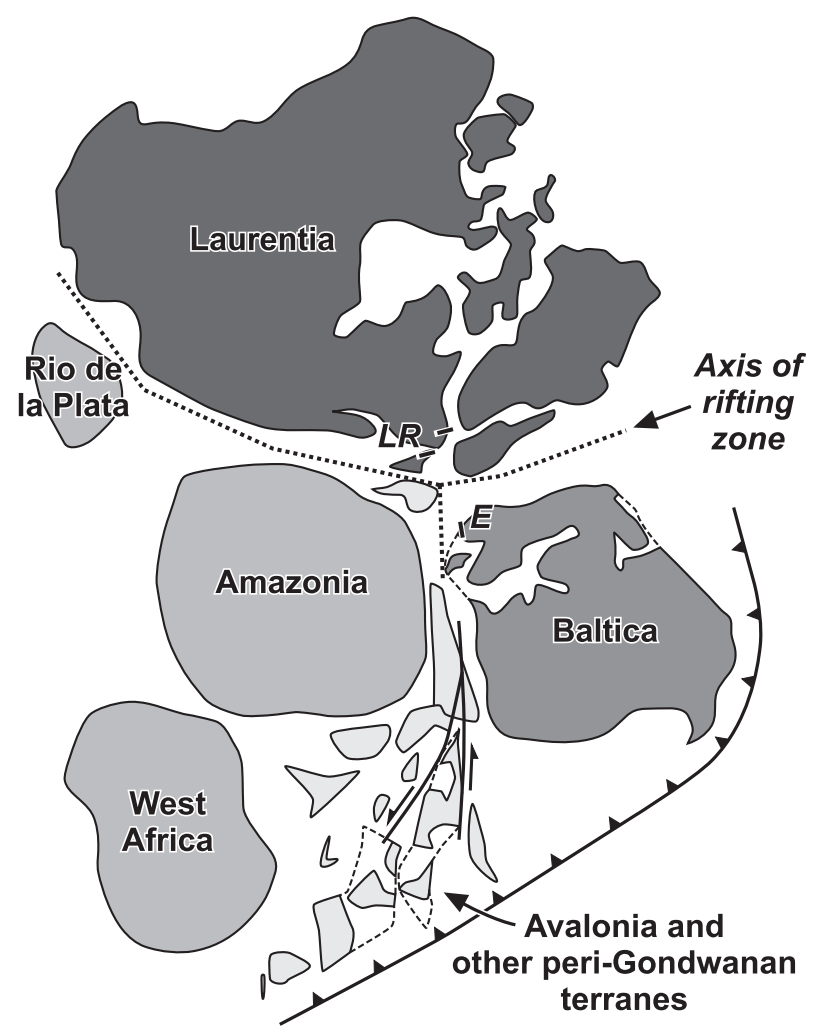

Fig. 15. Partial, schematic paleogeographic reconstruction of Rodinia at $\sim 615 \mathrm{Ma}$, i.e. before opening of the Iapetus Ocean, centered on Baltica, Laurentia and Amazonia (adapted from Pisarevsky et al., 2003; Cawood et al., 2007; Li et al., 2008; periGondwanan terranes and associated structures simplified after Murphy et al., 2004). E: Egersund dike swarm; LR: Long Range dike swarm.

\section{Geodynamic implications}

Classical paleogeographic reconstructions of Rodinia, before its breakup that led to opening of the Iapetus Ocean, consider conjugate margins of Laurentia and Baltica facing Amazonia, the Scandinavian margin of Baltica being juxtaposed to the LabradorianGreenland margin of Laurentia, with therefore a triple junction between the three assembled continents (Fig. 15; Torsvik et al., 1996; Dalziel, 1997; Pisarevsky et al., 2003; Cawood et al., 2007; Li et al., 2008). Starting from these reconstructions, magmatism occurring between 620 and $550 \mathrm{Ma}$ in Baltica and Laurentia along the three branches of the postulated triple junction is commonly attributed to continental rifting followed by diachronic opening of the Iapetus, beginning between Laurentia and Baltica and ending between Laurentia and Amazonia, with no consensus about the separation timing of Baltica and Amazonia (Bingen et al., 1998; Cawood et al., 2001; Cawood and Pisarevsky, 2006).

It is usually admitted that the Egersund dike swarm relates to the continental rifting preceding the opening of the Iapetus Ocean (e.g. Torsvik et al., 1996), dating the continental stretching in the area at $\sim 615$ Ma given the $616 \pm 3$ Ma intrusion age of the swarm (Bingen et al., 1998). Following the latter authors, this continental stretching probably led to the opening of the Tornquist arm of the Iapetus, between Baltica and Amazonia according to the pre-drift triple junction Baltica-Laurentia-Amazonia configurations, since the dikes are trending parallel to the SW margin of Baltica (presentday orientation; Fig. 15). The oblique opening of the Egersund dikes induced by a sinistral strike-slip, as recorded by the magnetic fabrics, implies that the swarm was not in a pure tensile regime, but in a sinistral transtension regime. In other words, the rifting recorded by the dike swarm that predated the opening of the Iapetus was oblique in the area. Admitting that the Egersund swarm witnesses the separation between Baltica and Amazonia (Bingen et al., 1998), which is realistic given its orientation, a sinistral strike-slip regime is consistent with the sinistral oblique subduction recorded along a distant active margin of Rodinia and responsible for the opening of intra-arc basins bounded by sinistral faults within the Avalonia terrane (Fig. 15; Murphy et al., 2004; and references therein).

\section{Conclusion}

Asymmetrical magnetic fabrics in the Egersund dikes are compatible with a composite simple shear resolved on dike walls, combining the magma shear and a syn-emplacement, sinistral strike-slip shearing. Such a component of strike-slip movement has never been mentioned in field studies of the Egersund swarm (Antun, 1955; Venhuis and Barton, 1986; Karlsen et al., 1998), strengthening the importance of a comprehensive AMS sampling in magmatic bodies such as dikes to reveal an internal fabric. The predominance of gently-plunging magma flow lines (gentlyplunging magnetic lineations) in the swarm is viewed as a consequence of magma freezing away from a deep-seated feeding zone, most probably associated with the strike-slip shearing.

The Egersund swarm is classically regarded as a syn-rift precursor of the opening of the Iapetus, probably the Tornquist arm of this ocean between Baltica and Amazonia, thus witnessing an early stage of the Rodinia breakup. The present study sheds new light on the geodynamics of the pre-drift continental rifting along the SW margin of Baltica (present-day orientation): the asymmetrical magnetic fabrics evidenced in the Egersund dikes imply that the rifting occurred in a context of oblique extension (transtension) characterized by a sinistral, strike-slip component.

To go further in the analysis of the Iapetus pre-drift geodynamics, the Long Range doleritic dike swarm of SE Labrador and NW Newfoundland, at the eastern margin of Laurentia (presentday orientation; Fig. 15) would be worth of an AMS study, in order to constrain the tectonic regime (transtensional vs. extensional) prevailing in the area before initiation of seafloor spreading. The Long Range dikes, coeval ( $615 \pm 2 \mathrm{Ma}$ ) with the Egersund dikes and with similar compositions were close to the latter at the emplacement time, according to many pre-drift reconstructions of Rodinia, on both sides of the postulated triple junction between Baltica, Laurentia and Amazonia (Fig. 15), the two swarms forming a "single large magmatic event related to a continental rifting" (Bingen et al., 1998).

\section{Acknowledgments}

Fieldwork was partially funded by the FNRS (National Funds for Scientific Research, Belgium). Technical assistance was provided by J.-P. Cullus (University of Liège). J.-L. Bouchez and an anonymous reviewer are thanked for their insightful and constructive reviews that significantly helped improving the manuscript. Journal editor I. Alsop is thanked for his comments and handling the manuscript.

\section{Appendix A. Supplementary data}

Supplementary data related to this article can be found at http:// dx.doi.org/10.1016/j.jsg.2016.01.006.

\section{References}

Antun, P., 1955. Géologie et pétrologie des dolérites de la région d'Egersund (Norvège méridionale) (PhD thesis). Université de Liège, p. 142. 
Arbaret, L., Diot, H., Bouchez, J.-L., 1996. Shape fabrics of particles in low concentration suspensions: 2D analogue experiments and application to tiling in magma. J. Struct. Geol. 18, 941-950.

Arbaret, L., Fernandez, A., Ježek, J., Ildefonse, B., Launeau, P., Diot, H., 2000. Analogue and numerical modelling of shape fabrics: application to strain and flow determination in magmas. Trans. R. Soc. Edinb. Earth Sci. 91, 97-109.

Arbaret, L., Mancktelow, N.S., Burg, J.-P., 2001. Effect of shape and orientation on rigid particle rotation and matrix deformation in simple shear flow. J. Struct. Geol. 23, 113-125.

Archanjo, C.J., Launeau, P., Bouchez, J.-L., 1995. Magnetic fabric vs. magnetite and biotite shape fabrics of the magnetite-bearing granite pluton of Gameleiras (Northeast Brazil). Phys. Earth Planet. Interiors 89, 63-75.

Aubourg, C., Giordano, G., Mattei, M., Speranza, F., 2002. Magma flow in subaqueous rhyolitic dikes inferred from magnetic fabric analysis (Ponza Island, W. Italy). Phys. Chem. Earth 27, 1263-1272.

Aubourg, C., Tshoso, G., Le Gall, B., Bertrand, H., Tiercelin, J.-J., Kampunzu, A.B., Dyment, J., Modisi, M., 2008. Magma flow revealed by magnetic fabric in the Okavango giant dyke swarm, Karoo igneous province, northern Botswana. J. Volcanol. Geotherm. Res. 170, 247-261.

Baer, G., 1995. Fracture propagation and magma flow in segmented dykes: field evidence and fabric analyses, Makhtesh Ramon, lsrael. In: Baer, G., Heimann, A. (Eds.), Physics and Chemistry of Dykes. Balkema, Rotterdam, pp. 125-140.

Barrière, M., 1976. Flowage differentiation: limitation of the "Bagnold effect" to the narrow intrusions. Contributions Mineral. Petrol. 55, 139-145.

Barton, M., van Bergen, M.J., 1984. Secondary ilvaite in a dolerite dyke from Rogaland, SW Norway. Mineral. Mag. 48, 449-456.

Bingen, B., Demaiffe, D., 1999. Geochemical signature of the Egersund basaltic dyke swarm, SW Norway, in the context of late-Neoproterozoic opening of the Iapetus Ocean. Nor. Geol. Tidsskr. 79, 69-86.

Bingen, B., Demaiffe, D., van Breeman, O., 1998. The 616 Ma old Egersund basaltic dike swarm, SW Norway, and late Neoproterozoic opening of the Iapetus ocean. J. Geol. 106, 565-574.

Bingen, B., Nordgulen, Ø., Viola, G., 2008. A four-phase model for the Sveconorwegian orogeny, SW Scandinavia. Nor. J. Geol. 88, 43-72.

Blanchard, J.-P., Boyer, P., Gagny, C., 1979. Un nouveau critère de sens de mise en place dans une caisse filonienne : le «pincement » des minéraux aux épontes. Tectonophysics 53, 1-25.

Bogdanova, S.V., Bingen, B., Gorbatschev, R., Kheraskova, T.N., Kozlov, V.I., Puchkov, V.N., Volozh, Y.A., 2008. The East European Craton (Baltica) before and during the assembly of Rodinia. Precambrian Res. 160, 23-45.

Borradaile, G.J., Gauthier, D., 2006. Magnetic studies of magma-supply and sea-floor metamorphism: Troodos ophiolite dikes. Tectonophysics 418, 75-92.

Borradaile, G.J., Jackson, M., 2004. Anisotropy of magnetic susceptibility (AMS): magnetic petrofabrics of deformed rocks. In: Martín-Hernández, F., Lüneburg, C.M., Aubourg, C., Jackson, M. (Eds.), Magnetic Fabric: Methods and Applications. J. Geol. Soc. Lond. Special Publ. vol. 238, 299-360.

Bouchez, J.-L., 2000. Anisotropie de susceptibilité magnétique et fabrique des granites. C. R. l'Acad. Sci. Paris Sci. Terre Planètes 330, 1-14.

Cadman, A., Tarney, J., Park, R.G., 1990. Intrusion and crystallisation features in Proterozoic dyke swarms. In: Parker, A.J., Rickwood, P.C., Tucker, D.H. (Eds.), Mafic Dykes and Emplacement Mechanisms. Balkema, Rotterdam, pp. 13-24.

Cadman, A.C., Park, R.G., Tarney, J., Halls, H.C., 1992. Significance of anisotropy of magnetic susceptibility fabrics in Proterozoic mafic dykes, Hopedale Block, Labrador. Tectonophysics 207, 303-314.

Callot, J.-P., Geoffroy, L., 2004. Magma flow in the East Greenland dyke swarm inferred from study of anisotropy of magnetic susceptibility: magmatic growth of a volcanic margin. Geophys. J. Int. 159, 816-830.

Callot, J.-P., Geoffroy, L., Aubourg, C., Pozzi, J.P., Mège, D., 2001. Magma flow directions of shallow dykes from the East Greenland volcanic margin inferred from magnetic fabric studies. Tectonophysics 335, 313-329.

Cañón-Tapia, E., 1996. Single-grain versus distribution anisotropy: a simple threedimensional model. Phys. Earth Planet. Interiors 94, 149-158.

Cawood, P.A., McCausland, P.J.A., Dunning, G.R., 2001. Opening lapetus: constraints from the Laurentian margin in Newfoundland. Geol. Soc. Am. Bull. 113, 443-453.

Cawood, P.A., Nemchin, A.A., Strachan, R., Prave, T., Krabbendam, M., 2007. Sedimentary basin and detrital zircon record along East Laurentia and Baltica during assembly and breakup of Rodinia. J. Geol. Soc. Lond. 164, 257-275.

Cawood, P.A., Pisarevsky, S.A., 2006. Was Baltica right-way-up or upside-down in the Neoproterozoic? J. Geol. Soc. Lond. 163, 753-759.

Clemente, C.S., Amorós, E.B., Crespo, M.G., 2007. Dike intrusion under shear stress: effects on magnetic and vesicle fabrics in dikes from rift zones of Tenerife (Canary Islands). J. Struct. Geol. 29, 1931-1942.

Correa-Gomes, L.C., Souza Filho, C.R., Martins, C.J.F.N., Oliveira, E.P., 2001. Development of symmetrical and asymmetrical fabrics in sheet-like igneous bodies: the role of magma flow and wall-rock displacements in theoretical and natural cases. J. Struct. Geol. 23, 1415-1428.

Creixell, C., Parada, M.Á., Morata, D., Roperch, P., Arriagada, C., 2009. The genetic relationship between mafic dike swarms and plutonic reservoirs in the Mesozoic of central Chile $\left(30^{\circ}-33^{\circ} 45^{\prime} \mathrm{S}\right)$ : insights from AMS and geochemistry. Int. J. Earth Sci. 98, 177-201.

Creixell, C., Parada, M.Á., Roperch, P., Morata, D., Arriagada, C., de Arce, C.P., 2006. Syntectonic emplacement of the Middle Jurassic Concón Mafic Dike Swarm, Coastal Range, central Chile (33 S). Tectonophysics 425, 101-122.

Dalziel, I.W.D., 1997. Neoproterozoic-Paleozoic geography and tectonics: review, hypothesis, environmental speculation. Geol. Soc. Am. Bull. 109, 16-42.

Delaney, P.T., Pollard, D.D., 1981. Deformation of Host Rocks and Flow of Magma during Growth of Minette Dikes and Breccia-bearing Intrusions Near Ship Rock, New Mexico. In: Geological Survey Professional Paper 1202.

Dunlop, D.J., Özdemir, Ö., 2009. Magnetizations in rocks and minerals. In: Kono, M. (Ed.), Treatise of Geophysics, Geomagnetism, vol. 5. Elsevier, Amsterdam, pp. 277-336.

Ernst, R.E., Baragar, W.R.A., 1992. Evidence from magnetic fabric for the flow pattern of magma in the Mackenzie giant radiating dyke swarm. Nature 356, 511-513.

Féménias, O., Diot, H., Berza, T., Gauffriau, A., Demaiffe, D., 2004. Asymmetrical to symmetrical magnetic fabric of dikes: paleo-flow orientations and paleostresses recorded on feeder-bodies from the Motru Dike Swarm (Romania). J. Struct. Geol. 26, 1401-1418.

Gaillot, P., de Saint Blanquat, M., Bouchez, J.-L., 2006. Effects of magnetic interactions in anisotropy of magnetic susceptibility: models, experiments and implications for igneous rock fabrics quantification. Tectonophysics 418, 3-19.

Geoffroy, L., Callot, J.-P., Aubourg, C., Moreira, M., 2002. Magnetic and plagioclase linear fabric discrepancy in dykes: a new way to define the flow vector using magnetic foliation. Terra Nova 14, 183-190.

Grégoire, V., Darrozes, J., Gaillot, P., Nédélec, A., Launeau, P., 1998. Magnetite grain shape fabric and distribution anisotropy vs. rock magnetic fabric: a threedimensional case study. J. Struct. Geol. 20, 937-944.

Grégoire, V., de Saint Blanquat, M., Nédélec, A., Bouchez, J.-L., 1995. Shape anisotropy versus magnetic interactions of magnetite grains: experiments and application to AMS in granitic rocks. Geophys. Res. Lett. 22, 2765-2768.

Hargraves, R.B., Johnson, D., Chan, C.Y., 1991. Distribution anisotropy: the cause of AMS in igneous rocks? Geophys. Res. Lett. 18, 2193-2196.

Hext, G.R., 1963. The estimation of second-order tensors, with related tests and designs. Biometrika 50, 353-373.

Jelínek, V., 1981. Characterization of magnetic fabric of rocks. Tectonophysics 79 T63-T67.

Jorde, K., Sigmond, E.M.O., Thorsnes, T., 1995. Geologisk kart over Norge, berggrunnskart Stavanger - 1:250000. Norges geologiske undersøkelse, Trondheim.

Karlsen, T.A., Nilsson, L.P., Schiellerup, H., Marker, M., Gautneb, H., 1998. Berggrunnsgeologisk kart over Åna-Sira anorthosittmassiv med omgivelser - 1 : 25000. Norges geologiske undersøkelse, Trondheim.

Knight, M.D., Walker, G.P.L., 1988. Magma flow directions in dikes of the Koolau complex, Oahu, determined from magnetic fabric studies. J. Geophys. Res. 93 (B5), 4301-4319.

Komar, P.D., 1976. Phenocryst interactions and the velocity profile of magma flowing through dikes or sills. Geol. Soc. Am. Bull. 87, 1336-1342.

Launeau, P., Cruden, A.R., 1998. Magmatic fabric acquisition mechanisms in a syenite: results of a combined anisotropy of magnetic susceptibility and image analysis study. J. Geophys. Res. 103 (B3), 5067-5089.

Launeau, P., Robin, P.-Y., 2005. Determination of fabric and strain ellipsoids from measured sectional ellipses - implementation and applications. J. Struct. Geol. 27, 2223-2233.

Launeau, P., Archanjo, C.J., Picard, D., Arbaret, L., Robin, P.-Y., 2010. Two- and threedimensional shape fabric analysis by the intercept method in grey levels. Tectonophysics 492, 230-239.

Lefort, J.-P., Aïfa, T., Hervé, F., 2006. Structural and AMS study of a Miocene dyke swarm located above the Patagonian subduction. In: Hanski, E., Mertanen, S. Rämö, T., Vuollo, J. (Eds.), Dyke Swarms - Time Markers of Crustal Evolution. Taylor and Francis Group, London, pp. 225-241.

Li, Z.X., Bogdanova, S.V., Collins, A.S., Davidson, A., De Waele, B., Ernst, R.E., Fitzsimons, I.C.W., Fuck, R.A., Gladkochub, D.P., Jacobs, J., Karlstrom, K.E., Lu, S., Natapov, L.M., Pease, V., Pisarevsky, S.A., Thrane, K., Vernikovsky, V., 2008. Assembly, configuration, and break-up history of Rodinia: a synthesis. Precambrian Res. 160, 179-210.

Lister, J.R., Kerr, R.C., 1991. Fluid-mechanical models of crack propagation and their application to magma transport in dykes. J. Geophys. Res. 96 (B6), 10049-10077.

Marker, M., Schiellerup, H., Meyer, G.B., Robins, B., Bolle, O., 2003. Geological map of the Rogaland anorthosite province - scale 1:75000. In: Duchesne, J.C., Korneliussen, A. (Eds.), Ilmenite Deposits and Their Geological Environment. With Special Reference to the Rogaland Anorthosite Province, Norges geologiske undersøkelse, Special Publication 9, Plate 1.

McEnroe, S.A., Brown, L.L., 2000. Palaeomagnetism, rock magnetism and geochemistry of Jurassic dykes and correlative redbeds, Massachusetts, USA. Geophys. J. Int. 143, 22-38.

Murphy, J.B., Pisarevsky, S.A., Nance, R.D., Keppie, J.D., 2004. Neoproterozoic-Early Paleozoic evolution of peri-Gondwanan terranes: implications for LaurentiaGondwana connections. Int. J. Earth Sci. 93, 659-682.

Park, J.K., Tanczyk, E.I., Desbarats, A., 1988. Magnetic fabric and its significance in the 1400 Ma Mealy diabase dykes of Labrador, Canada. J. Geophys. Res. 93 (B11), 13689-13704.

Pisarevsky, S.A., Wingate, M.T.D., Powell, C.M., Johnson, S., Evans, D.A.D., 2003. Models of Rodinia assembly and fragmentation. In: Yoshida, M., Windley, B.F. Dasgupta, S. (Eds.), Proterozoic East Gondwana: Supercontinent Assembly and Breakup, Geological Society, London, Special Publications 206, pp. 35-55.

Pollard, D.D., 1987. Elementary fracture mechanics applied to the structural interpretation of dykes. In: Halls, H.C., Fahrig, W.F. (Eds.), Mafic Dyke Swarms, Geological Association of Canada Special Paper 34, pp. 5-24.

Raposo, M.I.B., 2011. Magnetic fabric of the Brazilian dike swarms: a review. In: Petrovský, E., Herrero-Bervera, E., Harinarayana, T., Ivers, D. (Eds.), The Earth's 
Magnetic Interior, IAGA Special Sopron Book Series 1, pp. 247-262.

Raposo, M.I.B., D'Agrella-Filho, M.S., 2000. Magnetic fabrics of dike swarms from SE Bahia State, Brazil: their significance and implications for Mesoproterozoic basic magmatism in the São Francisco Craton. Precambrian Res. 99, 309-325.

Raposo, M.I.B., Ernesto, M., 1995. Anisotropy of magnetic susceptibility in the Ponta Grossa dyke swarm (Brazil) and its relationship with magma flow direction. Phys. Earth Planet. Interiors 87, 183-196.

Rickwood, P.C., 1990. The anatomy of a dyke and the determination of propagation and magma flow directions. In: Parker, AJ, Rickwood, P. Tucker, DH. (Eds.), Mafic Dykes and Emplacement Mechanisms. Balkema, Rotterdam, pp. 81-100.

Rochette, P., Jackson, M., Aubourg, C., 1992. Rock magnetism and the interpretation of anisotropy of magnetic susceptibility. Rev. Geophys. 30, 209-226.

Rochette, P., Jenatton, L., Dupuy, C., Boudier, F., Reuber, I., 1991. Diabase dikes emplacement in the Oman ophiolite: a magnetic fabric study with reference to geochemistry. In: Peters, T., Nicolas, A., Coleman, R.G. (Eds.), Ophiolite Genesis and Evolution of the Oceanic Lithosphere. Kluwer, Dordrecht, pp. 55-82.

Schärer, U., Wilmart, E., Duchesne, J.-C., 1996. The short duration and anorogenic character of anorthosite magmatism: U-Pb dating of the Rogaland complex Norway. Earth Planet. Sci. Lett. 139, 335-350.

Silva, P.F., Marques, F.O., Henry, B., Madureira, P., Hirt, A.M., Font, E., Lourenço, N. 2010. Thick dyke emplacement and internal flow: a structural and magnetic fabric study of the deep-seated dolerite dyke of Foum Zguid (southern Morocco). J. Geophys. Res. 115, B12108.

Staudigel, H., Gee, J., Tauxe, L., Varga, R.J., 1992. Shallow intrusive directions of sheeted dikes in the Troodos ophiolite: anisotropy of magnetic susceptibility and structural data. Geology 20, 841-844.
Svenningsen, O.M., 2001. Onset of seafloor spreading in the Iapetus Ocean at 608 Ma: precise age of the Sarek Dyke Swarm, northern Swedish Caledonides. Precambrian Res. 110, 241-254.

Tauxe, L., Gee, J.S., Staudigel, H., 1998. Flow directions in dikes from anisotropy of magnetic susceptibility data: the bootstrap way. J. Geophys. Res. 103 (B8), $17775-17790$.

Torsvik, T.H., Smethurst, M.A., Meert, J.G., Van der Voo, R., McKerrow, W.S., Brasier, M.D., Sturt, B.A., Walderhaug, H.J., 1996. Continental break-up and collision in the Neoproterozoic and Palaeozoic - a tale of Baltica and Laurentia. Earth-Sci. Rev. 40, 229-258.

Vander Auwera, J., Bolle, O., Bingen, B., Liégeois, J.-P., Bogaerts, M., Duchesne, J.-C., De Waele, B., Longhi, J., 2011. Sveconorwegian massif-type anorthosites and related granitoids result from post-collisional melting of a continental arc root. Earth-Sci. Rev. 107, 375-397.

Varga, R.J., Gee, J.S., Staudigel, H., Tauxe, L., 1998. Dike surface lineations as magma flow indicators within the sheeted dike complex of the Troodos Ophiolite, Cyprus. J. Geophys. Res. 103 (B3), 5241-5256.

Venhuis, G.J., Barton, M., 1986. Major element chemistry of Precambrian dolerite dikes of tholeiitic composition from Rogaland/Vest Agder, SW Norway. Nor. Geol. Tidsskr. 66, 277-294.

Walderhaug, H., 1993. Rock magnetic and magnetic fabric variations across three thin alkaline dykes from Sunnhordland, Western Norway; influence of initial mineralogy and secondary chemical alterations. Geophys. J. Int. 115, 97-108.

Walderhaug, H.J., Torsvik, T.H., Halvorsen, E., 2007. The Egersund dykes (SW Norway): a robust Early Ediacaran (Vendian) palaeomagnetic pole from Baltica. Geophys. J. Int. 168. 